University of Chicago Law School

Chicago Unbound

Public Law and Legal Theory Working Papers

Working Papers

2003

\title{
The Judiciary Is a They, Not an It: Two Fallacies of Interpretive Theory
}

Adrian Vermeule

Follow this and additional works at: https://chicagounbound.uchicago.edu/public_law_and_legal_theory

Part of the Law Commons

Chicago Unbound includes both works in progress and final versions of articles. Please be aware that a more recent version of this article may be available on Chicago Unbound, SSRN or elsewhere.

\section{Recommended Citation}

Adrian Vermeule, "The Judiciary Is a They, Not an It: Two Fallacies of Interpretive Theory " (University of Chicago Public Law \& Legal Theory Working Paper No. 49, 2003).

This Working Paper is brought to you for free and open access by the Working Papers at Chicago Unbound. It has been accepted for inclusion in Public Law and Legal Theory Working Papers by an authorized administrator of Chicago Unbound. For more information, please contact unbound@law.uchicago.edu. 


\title{
CHICAGO
}

Public Law and Legal Theory Working Paper No. 49

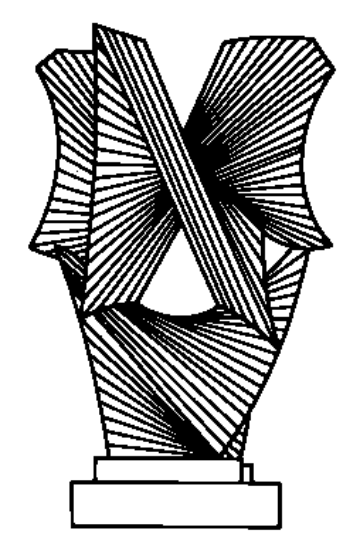

\section{THE JUDICIARY IS A THEY, NOT AN IT: \\ TWO FALLACIES OF INTERPRETIVE THEORY}

\author{
Adrian Vermeule
}

THE LAW SCHOOL

THE UNIVERSITY OF CHICAGO

September 2003

This paper can be downloaded without charge at

http://www.law.uchicago.edu/academics/publiclaw/index.html

and at The Social Science Research Network Electronic Paper Collection:

http://ssrn.com/abstract_id= 


\title{
THE JUdiCIARY Is A THEY, Not AN IT: Two FALlACIES OF INTERPRETIVE THEORY
}

\author{
Adrian Vermeule
}

Consider the following arguments about constitutional and statutory interpretation. All of these arguments are widely discussed in the legal literature, especially in the most fashionable recent work on dynamic approaches to interpretation; all of them are widely viewed as at least credible or plausible, whether or not they are ultimately persuasive:

- Judges should adopt canons of statutory interpretation that require a clear legislative statement - for example, the canon that statutes should be construed to avoid serious constitutional questions - in order to promote beneficial legislative deliberation about constitutional values or important policy questions.

- Judges should adopt constitutional rules that enforce "due process of lawmaking"for example, requirements of congressional factfinding under statutes that enforce the 14th Amendment - in order to promote a well-functioning legislative process.

- Judges should adopt textualism because it has a disciplining effect, ex ante, on legislatures and other drafters of legal texts.

- Each judge should decide what is, in her judgment, the best approach to constitutional and statutory interpretation, and then adopt it.

- Each senator who must vote on the confirmation of a judge or justice should decide what is, in her judgment, the best approach to constitutional and statutory interpretation, and then vote to confirm if, and only if, the nominee has adopted that approach.

In what follows I shall take on a heavy burden. I shall attempt to show that each of these arguments, and others like them (in ways I shall specify below), are logically fallacious. The point is not that these arguments are substantively incorrect, on the merits. The thesis is a more ambitious one: the arguments are conceptually confused, and thus do not count as valid arguments at all. Each of them commits the fundamental mistake of overlooking the collective character of judicial institutions - of overlooking that the judiciary, like Congress, is a 'they,' not an 'it." That mistake produces the critical, and erroneous, assumption that coordinated judicial adoption of some particular approach to

\footnotetext{
* Professor of Law, The University of Chicago. Thanks to Elizabeth Garrett, Eric Posner, David Strauss, Cass Sunstein, David Weisbach and participants at a University of Chicago faculty workshop for helpful comments and conversations, and to Eric Truett and Carli Spina for excellent research assistance. Thanks to the Russell J. Parsons Faculty Research Fund for generous financial assistance.

${ }^{1}$ With apologies to Kenneth A. Shepsle, Congress is a "They," Not an "It": Legislative Intent as Oxymoron, 12 Int'l Rev. L. \& Econ. 239 (1992).
} 
legal interpretation is both feasible and desirable. Once we drop that assumption, it becomes clear that the premises implicit in these arguments do not support their conclusions. In some cases the conclusions may still hold, independently; but they would have to be justified, if at all, on entirely different grounds.

The key to the analysis is a matched pair of logical fallacies that are pervasive in interpretive theory: the fallacies of division and composition. Although each fallacy has been given several, subtly different definitions, ${ }^{2}$ for present purposes we may usefully say that each rests on a mistaken treatment of factual or normative generalization. The fallacy of division arises when a claim that is true of, or justified for, a whole set is taken to apply to any particular member of the set. That an army is strong does not entail that any one of its soldiers is strong; that the world would be better if all nations disarmed does not entail that any particular nation should disarm unilaterally. ${ }^{3}$ The fallacy of composition arises when a claim that is true of, or justified for, any particular member of a set is taken to apply to the whole set. That each particular member of a jury has decided views about the defendant's guilt or innocence does not entail that the jury as a whole has a decided view; its members' views may not be unanimous. In a group of mountaineers scaling Everest, it is sensible for some member to forego the final ascent in order to secure the base camp. It would hardly be sensible for the whole group to do so. ${ }^{4}$

Problems of division and composition occur when, and because, theorists of legal interpretation overlook that the judiciary is a collective body, not a single individual. The failure to appreciate that large fact about judicial institutions causes interpretive theorists to stumble into the mistakes about generalization that go under the rubrics of division and composition. Generalization problems arise when legal theorists ask, explicitly or implicitly, the following question: "what is the best interpretive approach for judges (or courts) to adopt?" That question omits an essential feature of the problem. Imagine that a given judge, any judge, is deciding whether to be a textualist, an originalist, a purposivist, or something else, and has turned to the academic literature on interpretive theory for guidance -- however counterfactual this picture may be. The legal theorists' counsel speaks to the question which approach would be best if adopted by "the judges" (or "the courts"). But that is not the question that our particular judge needs to answer. Our judge

\footnotetext{
${ }^{2}$ Although introductory works in logic offer definitions of the two fallacies, see, e.g., Stephen Toulmin, An Introduction to Reasoning (2d ed. 1984) 171-72, several different definitions are plausible, each with subtly different emphases or implications. See infra note ---. For a different application of the two fallacies to legal problems, see Michael Herz, Justice Byron White and the Argument that the Greater Includes the Lesser, 1994 B.Y.U. L. Rev. 227, 243.

${ }^{3}$ In the first example the division problem arises because of a semantic equivocation: "strong" has two relevant senses. In the second example the problem seemingly stems from a causal confusion -- a form of magical thinking in which Nations 1's disarmament will somehow cause Nations 2 through $\mathrm{N}$ to reciprocate. We might, or might not, want to define the division and composition fallacies to cover both semantic equivocation and causal mistakes; analytic philosophers and social theorists have debated such matters inconclusively. See, e.g., William L. Rowe, The Fallacy of Composition, 71 Mind 87 (1962); Jon Elster, Logic and Society 97-106 (1978). For my less refined purposes the precise source of generalization mistakes, and the precise definition of the two fallacies, are immaterial. All I mean to do is to use division (and composition) as a shorthand label for a complex of conceptual errors, arising from mistakes about generalization, that show important family resemblances.

${ }^{4}$ Of the examples in this paragraph, the army and the jury are taken from Elster, supra note, at 98.
} 
wants to know what approach is best for her to adopt. The two questions will have very different answers if the other judges adopt different theories of interpretation than she adopts.

Two points are critical here. First, that a given approach would be best for the whole court or judiciary does not entail that it would be best for any given judge taken alone. The inference from the group-level claim to the individual-level claim fails if judicial coordination on a particular approach is infeasible or unlikely. The best approach for any given judge to adopt will vary depending on whether the other judges adopt the same approach, or instead adopt (any of several) other approaches, either because they disagree with the first judge's normative conclusions, because they are incapable of full compliance with the relevant prescriptions, or for some other reason. Second, and conversely, that a particular approach is best for any given judge need not entail that it would be best for the whole court (or judiciary). If a diversity of approaches is desirable for systemic and institutional reasons, then it would be an affirmative bad for all the judges to coordinate on a particular approach. To overlook the first point is to commit the division fallacy; to overlook the second is to commit the composition fallacy. And, of course, the same reasoning applies from the standpoint of every judge in the system.

In this picture, the interpretive theorist has gone wrong by casting the critical question at an excessively high level of abstraction. For reasons I will explore below, the collective structure of judicial institutions means that it is simply inadequate to theorize about interpretation as if the judiciary were a unitary institution, perhaps conceived as a single individual. ${ }^{5}$ In the language of moral philosophy, the interpretive theorist has overlooked essential questions of nonideal theory, which asks what obligations people have when others will not or cannot comply with their (identical) obligations. ${ }^{6}$ In the language of economics and consequentialist political theory, the interpretive theorist has overlooked essential questions of the second-best, which arise when a general or collective equilibrium cannot be attained. Whatever metaphor is best, the core problem is that the theorist has gone wrong by omitting essential institutional detail. It is an irony of interpretive theory that so much emphasis has been given to exploring the consequences of the legislature's collective character, ${ }^{7}$ while inadequate attention has been paid to the same problem in judicial institutions. ${ }^{8}$

\footnotetext{
${ }^{5}$ This is so whether or not the single judge resembles Hercules. See Ronald Dworkin, Law's Empire (1986). Dworkin's stylized adjudicator both possesses superhuman capacities and also sits as a single-judge court. An objection to the first assumption is that, in fact, no real judges possess superhuman capacities. See, e.g., Adrian Vermeule \& Ernest A. Young, Hercules, Herbert, and Amar: The Trouble with Intratextualism, 113 Harv. L. Rev. 730 (2000). Here I mean to press an objection to the second assumption: the collective character of judicial institutions undermines any analytic approach that presupposes a unitary interpreter.

${ }^{6}$ See Liam Murphy, Moral Demands and Non-Ideal Theory (2000); Edna Ullman-Margalit, The Generalization Argument: Where Does the Obligation Lie, 73 Journal of Philosophy 511 (1976).

${ }^{7}$ Jeremy Waldron, Law and Disagreement, Chapter 10 (1999); Jeremy Waldron, The Dignity of Legislation (1999); Shepsle, supra note

${ }^{8}$ The claim is not that legal theory generally has ignored the collective character of judicial decisionmaking. Important literatures in social choice and voting theory have explored aggregation problems on multi-judge courts. See Frank H. Easterbrook, Ways of Criticizing the Court, 95 Harv. L. Rev. 802 (1982); Lewis A. Kornhauser \& Lawrence G. Sager, Unpacking the Court, 96 Yale L.J. 82 (1986); David Post \& Steven C. Salop, Rowing Against the Tidewater: A Theory of Voting by Multijudge Panels, 80 Geo. L.J. 743 (1992); Maxwell L. Stearns, The Condorcet Jury Theory and Judicial Decisionmaking: A
} 
Part I examines interpretive theories, methods and doctrines that commit the division fallacy. After examining circumstances in which any particular judge might do badly to adopt an interpretive approach that might be best if adopted by the whole judiciary, I will suggest that a range of interpretive doctrines are fallacious in this way. This point knocks out arguments that would justify textualism by its disciplining effect on legislatures; that justify canons of construction, or interpretive default rules, by pointing to their democracy-forcing or information-eliciting effects; or that justify constitutional rules by reference to their beneficial effects on the lawmaking process. The common conceptual mistake in these arguments is the undefended assumption that sustained judicial coordination on a particular interpretive approach or canonical regime is feasible. Whether it is feasible is an empirical question; I shall give tentative reasons for believing that it is not feasible, in our system anyway. To the extent that coordination across judges is not feasible, I shall also claim, it will often be affirmatively harmful or perverse for any particular judge to adopt the approach that would be best if all judges coordinated on it.

Part II provides a parallel analysis for the composition fallacy, examining reasons why a court or judiciary might do badly to adopt a given approach even if particular judges might do well to adopt that same approach. Where these reasons hold, they suggest that judicial coordination on a particular approach may be not only infeasible, but also affirmatively undesirable. New or additional judges joining a court should, at the margin, adopt the interpretive theory that will produce a diverse mix of approaches on the court as a whole. The import of this view for constitutional and statutory interpretation is that the best judiciary will include an appropriate mix of interpretive formalists (or textualists) and functionalists (or purposivists).

Part III canvasses some persistent themes in legal theory that tend to promote generalization mistakes: modeling imperatives, in which the judiciary is treated as a unitary actor to make formalization more tractable; the approximation assumption, or the fallacious belief that if an ideal is unattainable the best course is to approach that ideal as closely as possible; and, related to the last point, the tendency to see individual judges as creative artisans rather than as a special type of bureaucrat acting within a collective decisionmaking institution. In the conclusion, as throughout, I suggest that interpretive theory based on first principles must be supplemented by nonideal interpretive theory. Any account of constitutional and statutory interpretation should address interpretation as it actually occurs, in a collective judicial structure that produces intractable disagreement,

Reply to Saul Levmore, 3 Theoretical Inquiries L. 125 (2002); Evan H. Caminker, Sincere and Strategic Voting Norms on Multimember Courts, 97 Mich. L. Rev. 2297 (1999). There is also a growing literature in political science on intracourt strategic behavior, see, e.g., Forrest Maltzman, James F. Spriggs II, \& Paul J. Wahlbeck, Crafting Law on the Supreme Court (2000), and on the relationship between higher and lower courts in a hierarchy, see, e.g. McNollgast, Politics and The Courts: A Positive Theory of Judicial Doctrine and The Rule of Law, 68 S. Cal. L. Rev. 1631 (1995); Matt Reddick \& Sara C. Benesh, Norm Violation by the Lower Courts in the Treatment of Supreme Court Precedent: A Research Framework, 21 Just. Sys. J. 117 (2000); Matt Spitzer \& Eric Talley, Judicial Auditing, 29 J. Legal Stud. 649 (2000). For a valuable overview, with applications to constitutional theory, see Barry Friedman, The Politics of Judicial Review (draft on file with author). But these literatures have not, to date, penetrated far into interpretive theory, particularly the rapidly growing literature on interpretive default rules and canonical interpretive regimes. The interpretation literature overwhelmingly tends to persist in treating the judiciary as a unitary actor. See infra notes (providing examples). 
doctrinal and methodological inconsistency over time, and partial compliance with shared norms.

\section{The FALLACY OF Division}

Section A lays some conceptual groundwork and delineates the scope of the inquiry. Sections B and C turn to examples from statutory and constitutional interpretation, respectively.

A. Judicial Coordination and Interpretive Method

The division fallacy is to suppose that an interpretive strategy that would be beneficial if adopted by all judges should therefore be adopted by any particular judge. Whether the conclusion holds depends on what other judges are doing. Judges vote on cases within a collective judicial bureaucracy that, at appellate levels, always sits on merits cases in multi-judge panels. The collective character of judicial institutions produces several reasons for believing that (or circumstances in which) a particular judge might do badly to adopt an approach that would be best if adopted by all judges. The essential idea is that interpretive accounts that explicitly or implicitly require a whole court, or the whole judiciary, to coordinate on a given course of action, and to sustain that course of action over time, demand too much of judicial institutions.

There are two separate and independent points here, one analytic, the other empirical. Analytically, the premise that it would be best for all judges to coordinate on a given approach does not, without more, yield the conclusion that any particular judge ought to adopt that approach. Whether that is so depends upon what other judges do. Empirically, it is often costly or simply infeasible for the judiciary to coordinate upon a particular course of action, and to sustain that coordination to the degree necessary to affect the behavior of other institutions and actors. Much more work would have to be done to substantiate the empirical claim, but the opposite assumption-that judges can easily coordinate on approach that would be best for whole system (if it were agreed what approach that is) - is also unsubstantiated. Neither position has any natural or methodological priority; until the needed work has been done we can do no better than proceed on the basis of casual empiricism and informed impressions about the feasibility of judicial coordination.

We need to be clear, at the outset, that the division fallacy only bites against interpretive accounts that explicitly or implicitly require coordinated judicial action. Some accounts lack this character; a few theorists seem to hold the view that the Constitution, rightly understood, directly prescribes rules of constitutional and statutory interpretation that any individual judge is obliged to follow, regardless of what other judges do. ${ }^{9}$ Claims of this sort do not present division problems because they exclude any reference to the collective character of judicial institutions (although the price of avoiding division problems is that these accounts require an implausible reading of the Constitution, which says very little, directly or indirectly, about methods of legal interpretation). ${ }^{10}$ But the marked trend in interpretive theory has been towards "dynamic"

\footnotetext{
${ }^{9}$ See, e.g., John Manning, Textualism as Nondelegation Doctrine, 97 Colum. L. Rev. 673 (1997).

${ }^{10}$ As I have argued at length elsewhere. See, e.g., Adrian Vermeule, Interpretive Choice, 75 NYU L. Rev. 74 (2000); Cass R. Sunstein \& Adrian Vermeule, Interpretation and Institutions, 101 Mich. L. Rev. 885 (2003).
} 
accounts that do require or assume coordinated judicial action. And the division problem does bite on those accounts. Embedded structural features of judicial institutions, which I shall now survey, block the necessary coordination.

\section{Irreducible disagreement}

The most important practical consequence of the collective character of the judiciary is to produce irreducible disagreement within the judiciary about competing interpretive approaches - both disagreement within panels or courts and, over time, across panels or courts. The history of interpretive theory in American courts is, above all, a history of persistent and deep disagreements among judges and courts about the proper methods and sources of legal interpretation. As to methods, judges who emphasize the ordinary meaning of constitutional and statutory text criticize those who emphasize the purposes of framers or legislators, who in turn criticize devotees of specific legislative intentions; each of these groups itself fractures into competing variants. As to sources, the history of American interpretation is full of cases that have become chestnuts precisely because text, history, interpretive canons, constitutional and statutory policies, and other sources pull in different directions in those cases, forcing judges to make consequential choices about their priorities. The competing camps of interpretive theory are not (solely) scholastic inventions; they reflect chronic, possibly intractable, differences in judicial views about the proper treatment of recurring interpretive problems.

To be sure, the scope of judicial disagreement will be reduced, and its consequences ameliorated, to the extent that judges reach "incompletely theorized agreements" 11 about interpretation. In the most optimistic story, judges who disagree on high-level principles will converge upon particular rules, canons or statutory techniques. ${ }^{12}$ Consider the possibility, for example, that both textualists and intentionalists might converge on a rule excluding legislative history, the former because they think it irrelevant in principle, the latter because they come to believe, empirically, that legislative history misleads judges about legislative intent. A less useful version of the incompletely theorized agreement, however, occurs when judges who agree on high-level principles find that they disagree about a wide range of particular interpretive canons, rules or problems. Self-described intentionalists might sharply disagree about, for example, the intentionalist value of rejected legislative proposals. The extent and scope of disagreement will also be heavily sensitive to the type of court at issue. The base rate, for most lower appellate courts, is a great deal of agreement in any type of case, so it isn't surprising to find agreement on many statutory and constitutional cases as well. ${ }^{13}$ At the Supreme Court level, however,

\footnotetext{
${ }^{11}$ Cass R. Sunstein, Incompletely Theorized Agreements, 108 Harv. L. Rev. 1733 (1995).

${ }^{12}$ For an empirical study whose findings emphasize this point, albeit a study conducted on a very limited scale, see Daniel A. Farber, Do Theories of Statutory Interpretation Matter? A Case Study, 94 Nw. U. L. Rev. 1409 (2000). Examining four (!) Seventh Circuit opinions in which Judges Easterbrook and Posner voted for different judgments, Farber finds that the choice between formalist and antiformalist interpretive methods did little to determine the two judges' votes. Note, however, that interpretive theories might "matter" in many other senses than their effect on outcomes in particular cases. To take only one example, different interpretive approaches that converge on outcomes might nonetheless entail very different decision costs. If formalist judges reach a given result after reading a short chunk of statutory text while purposivist judges reach the same result after reading a few hundred pages of legislative history, the systemic costs of the two approaches will differ markedly even if outcomes do not.

${ }^{13}$ Farber quite properly acknowledges this about his findings. See supra note ---, at 1411.
} 
cases are harder, disagreements are sharper, and the effectiveness of precedent in dampening theoretical disagreement is reduced.

The most we can say, in the abstract, is that the possibility of muting disagreement in these ways needs much more empirical assessment than it has received so far. But a rudimentary acquaintance with American interpretive theory and practice suggests that, when the empirical work is done, some quantum of irreducible and important disagreement will be found to pervade the judiciary, not only between or among coordinate courts, such as the lower federal appellate courts, but also within courts. As their opinions suggest, judges really do differ about interpretive methods, tools, and even outcomes. Any judge who thinks that it would be better for the court, or the judiciary as a whole, to adopt Method A rather than Method B must consider the possibility that the next judge over is equally convinced that Method B would be the best approach-not merely for that judge, but for all concerned.

\section{Inevitable mistakes and noncompliance}

Even where disagreement is absent, or at least not openly debated, different judges may do different things with similar statutory problems. Judges' behavior may differ even if their (stated) principles do not. An important possibility is sheer human error resulting from the cognitive load under which judges labor. Judges, like others, face important shortages of time, information, and theoretical acumen. Decisions interpreting statutory and constitutional provisions will, with nontrivial frequency, announce rationales or reach results that contradict widely agreed-upon interpretive rules, and thus count as mistakes from any normative perspective. In a large number of these cases the judges who issued the decisions might themselves condemn the decision, if reviewing it without constraints of time and information. But the feedback mechanisms that might promote this form of learning are feeble in the extreme. Judges rarely have the leisure to reevaluate old decisions, unless a higher court reverses the decision and sends it back; even then, of course, the lower judge may attribute the reversal to principled disagreement or partisan biases, rather than acknowledge that his initial decision was mistaken.

Less commonly, but more dramatically, we might imagine situations in which some judges engage in bad-faith noncompliance with agreed-upon interpretive rules. Very few deny that there is some domain, perhaps a large domain, of easy interpretive cases - cases in which the obvious meaning of a legal text captures a straightforward linguistic, legal and social consensus, one that corresponds to a sensible account of constitutional or statutory polices, and in which other sources of meaning, if checked, would confirm the obvious meaning. Judges motivated by strongly-held policy convictions that run counter to the text may write opinions that erroneously classify easy cases as hard ones, exaggerating minor statutory quirks into ambiguities that may be resolved with reference to grandiose claims about background interpretive principles. ${ }^{14}$ In some fraction of cases the Supreme Court may eventually correct the lower courts' mistake, but it is unclear

\footnotetext{
${ }^{14}$ An example in the latter category, in my view, is the Supreme Court's famous decision in Holy Trinity Church v. United States, 143 U.S. 457 (1892). See Adrian Vermeule, Legislative History and the Limits of Judicial Competence: The Untold Story of Holy Trinity Church, 50 Stanford L Rev. 1833 (1998). For a contrary view, see Carol Chomsky, Unlocking the Mysteries of Holy Trinity: Spirit, Letter, and History in Statutory Interpretation, 100 Colum. L. Rev. 901 (2000).
} 
how often this occurs; as we shall see below, Supreme Court review is probably inadequate to squeeze all disagreement and error out of the interpretive system.

\section{Aggregation problems and cycling}

Under certain circumstances, the distribution of views across a multi-judge court may produce Condorcetian voting cycles, in which judges who may choose from any one of three or more positions find that a majority coalition exists to defeat each position. ${ }^{15}$ Even if the judges' individual views are well-ordered, the collective ordering is intransitive, and therefore (in one sense of the term) incoherent, ${ }^{16}$ even irrational. Voting cycles of this sort may be suppressed by adopting a rule that arbitrarily stops the cycle at some point (such as a doctrine of stare decisis), but this empowers agenda-setters because the content of law becomes highly sensitive to the order in which cases arise. ${ }^{17}$ Arrow's Theorem demonstrates that no decision rule can avoid this dilemma, given certain reasonableseeming stipulations about admissible views and permissible ways of ordering those views.

The significance of cyclical voting is unclear. Under reasonable empirical assumptions, the arrangement of views across judges frequently displays no collective instability ("single-peaked preferences") or are sufficiently homogenous that the most contestable stipulations of Arrow's Theorem do not apply (Sen's “value-restricted preferences"). The sole point relevant here is that the work on judicial voting cycles generalizes fully from substantive views to methodological positions -- to the choice of rules for constitutional and statutory interpretation. On a three-judge court, let us imagine, there are three possible views about the use of originalist evidence in constitutional interpretation. View 1 is that it should never be used; View 2 is that it should always be used; View 3 is a plain-meaning rule, under which the material is used only when the constitutional text is ambiguous or vague. The three judges rank these approaches differently. Judge A is a committed originalist: she believes that originalist evidence should always be used, but if that position is ruled out, she believes that it should at least be used in cases of textual ambiguity. (Judge A, that is, ranks the approaches in the order 2-3-1). Judge B is hostile to originalism, and believes that the material should never be used; but if it is to be used, Judge B think that it is unrealistic to attempt to cabin it by a plain-meaning rule. (So Judge B ranks the approaches 1-2-3). Judge $\mathrm{C}$ think the plain-meaning approach best, but if that is rejected, thinks that total disavowal of originalist material is better than unrestricted use. (So Judge $C$ ranks the approaches 3-1-2). Under this distribution of views, the court's method of constitutional interpretation will cycle endlessly or, if stare decisis applies to rules about interpretation, stop arbitrarily.

\footnotetext{
${ }^{15}$ Easterbrook, supra note

${ }^{16}$ For an exposition of various relevant senses of incoherence, see Kornhauser and Sager, supra note

17 This effect is usually described as "path dependence," but that term has multiple meanings, and is often invoked inaccurately, so I prefer to avoid it here. For a taxonomy of the term's various senses, see Oona A. Hathaway, Path Dependence in the Law: The Course and Pattern of Legal Change in a Common Law System, 86 Iowa L. Rev. 601 (2001).
} 


\section{Exogenous and endogenous change}

In some periods methodological disagreements, mistakes, and aggregation problems are temporarily muted or restrained by political consensus or aggressive Supreme Court oversight. An observer of American legal interpretation circa 1965, for example, might have thought that legislators, agencies and judges had coordinated on a shared set of interpretive tools and methods praised by legal-process theorists. Those methods prominently featured balancing tests in constitutional interpretation, purposive statutory interpretation, and easy recourse to legislative history.

But this sort of coordination of the interpretive system is rarely stable, and rarely lasts for long. One possibility is that exogenous social shocks, arising from political, economic, and technological developments, will call into question the empirical premises on which the prevailing consensus rests and change the political valence of interpretive methods. Another possibility is endogenous oscillation between or among interpretive methods, which can operate either in place of or in addition to exogenously-driven change. Consider the possibility that judicial use of legislative history will oscillate over time, because increased use will cause legislators to pollute the history with obviously unreliable material, causing judges to downplay its importance, causing legislators to reduce their efforts at manipulation, and so on. ${ }^{18}$

Even if judges craft a temporarily stable interpretive consensus, it may have no effect at all on legislative behavior in the short or medium term, just because of the lag-time built into the interpretive system. Old statutes (statutes enacted before the courts announced the new interpretive rule) will take some time to proceed through the lower courts and receive a definitive Supreme Court construction, or a definitive adjudication of their constitutional validity. By the time new statutes (enacted after the newly-announced rule) present themselves, the Court's composition may have changed, or new alliances and new doctrines may have formed. For an example of this dynamic, consider that the Rehnquist Court has formulated several interpretive doctrines intended to increase congressional respect for federalism, such as the requirement of detailed congressional factfinding under statutes that enforce the Fourteenth Amendment against states. ${ }^{19}$ Those doctrines have, in most cases, been applied to statutes enacted before the new doctrine was announced. ${ }^{20}$ By the time new statutes dominate the pool of litigated cases, the Rehnquist Court, and the relevant interpretive doctrines, will probably have passed into history.

Apart from the dynamic interplay between courts, legislatures and agencies, endogenous change may arise from interpersonal dynamics within courts. One possibility is that, on the Supreme Court, various Justices alter their interpretive positions over time in response to the positions colleagues take. Dynamics of this sort can occur if, for example, some Justices wish to occupy the Court median while the Court as a whole is

\footnotetext{
18 Adrian Vermeule, The Cycles of Statutory Interpretation, 68 U. Chi. L. Rev. 149 (2001).

${ }^{19}$ See infra notes ---.

${ }^{20}$ College Sav. Bank v. Florida Prepaid Postsecondary Educ. Expense Bd., 527 U.S. 666 (1999)(invalidating the Trademark Remedy Clarification Act's application to states); Board of Trustees of Univ. of Ala. v. Garrett, 531 U.S. 356 (2001) (invalidating the application of the Americans with Disabilities Act to states); Kimel v. Florida Bd. of Regents, 528 U.S. 62 (2000) (invalidating the application of the ADEA to states because Congress had exceeded their power under $\S 5$ of the Fourteenth Amendment).
} 
shifting to the right or left, if some Justices move towards extremes to occupy roles left vacant by the departure of other members, or if like-minded Justices polarize towards extreme views; I will take up the last possibility in more detail below.

In light of these possibilities, it is unsurprising (though not predictable ex ante) that the legal process consensus had been shattered by the mid-1980s, after the resurgence of the Republican Party and the appointment of a cadre of conservative judges. All of the major elements of the legal-process consensus were either been discarded or were subject to serious critiques. Constitutional balancing tests were on the intellectual defensive, ${ }^{21}$ both constitutional and statutory interpretation were animated by newly formalistic approaches, including textualism and originalism; and legislative history had come under attack as legally irrelevant and excessively manipulable. For present purposes it does not matter whether the relevant changes were caused by exogenous political change or reflected endogenous oscillation or judicial dynamics of some kind. The important point is that interpretive method is highly unstable, at least in the medium and long term.

\section{The structure of judicial institutions}

Taken singly or collectively, these institutional facts-irreducible disagreement, mistakes and noncompliance, aggregation problems, and change over time -- undercut any argument that implicitly requires that a given interpretive approach be adopted by all judges (if it is to work for any judge) and sustained for long periods. Whatever interpretive account of this sort a given judge adopts, other judges will adopt different ones, both at the same time and over time. The heterogeneity of interpretive approaches will block the implicit generalization on which the relevant approaches depend.

A tempting mistake here is to think that heterogeneity and fluctuation cannot exist in a hierarchical court structure, one topped by a high court with power to lay down systemwide interpretive rules and to bind lower courts to substantive results. But the picture of a centralized, hierarchical judiciary is fantastic. It omits a number of institutional fault lines, internal to the structure of judicial institutions, that hamper judicial coordination on interpretive strategies:

Divisions within lower courts. Sometimes, or on some questions, lower courts follow a unified course of action within a common legal and intellectual framework. Often, however, they do not. Putting aside the district courts, whose judges are largely free to pursue their preferred interpretive and substantive policies in cases that the parties will not appeal (perhaps because they have been strongly encouraged to settle), the circuit courts are hardly a monolithic, unified actor. In some cases there are strong substantive disagreements across circuits; in some cases circuit mechanisms for internal coordination are unwieldy; ${ }^{22}$ most simply, messiness is pervasive just because there are hundreds of appellate judges spread across more than a dozen lower courts. Importantly, there is no a priori guarantee that certiorari review will bring uniformity to lower-court

\footnotetext{
${ }^{21}$ T. Alexander Aleinikoff, Constitutional Law in the Age of Balancing, 96 Yale L.J. 943 (1987).

${ }^{22}$ Consider the Ninth Circuit's cumbersome two-level process for en banc review, in which a case is first reheard by a panel of eleven judges, including the Chief Judge if possible. Only after this initial rehearing, if the case is deemed an appropriate candidate, may the Court order a second rehearing by the full court. Fed. R. App. Pro. 35 ( $9^{\text {th }}$ Cir. 2003).
} 
decisionmaking. ${ }^{23}$ Whether it does so is an empirical question that has received insufficient study, ${ }^{24}$ and that will undoubtedly have different answers in different legal contexts and in different eras.

Noncompliance by lower courts. Another possibility is that lower courts, or a critical subset of them, will defy the Supreme Court's instructions, more or less covertly. Canonical examples are the district courts' foot-dragging after Brown v. Board of Education, ${ }^{25}$ and, from a later period, the D.C. Circuit's sustained pattern of noncompliance with, even defiance of, the Supreme Court's instructions for interpreting the Administrative Procedure Act. ${ }^{26}$ The possibility of defiance, at least on some issues and for some period, should be unsurprising. Although lower-court judges may experience a reputational cost if the Court reverses their decisions or admonishes them in a written opinion, it is hardly clear that the Court has the institutional capacity to catch an appreciable fraction of noncompliant decisions; and of course the Court cannot subject theoretically subordinate judges to any serious, direct sanctions, such as financial penalties.

A notable recent example of lower-court recalcitrance involves the Commerce Clause. Despite two prominent Supreme Court decisions invalidating federal statutes for exceeding the Clause's boundaries, lower courts have consistently declined the Supreme Court's apparent invitation to expand the new analysis to statutes such as the Endangered Species Act, the Freedom of Access to Clinic Entrances Act, or various federal statutes that criminalize possession of machine guns and drugs. ${ }^{27}$ Remarkably, lower court judges have, in recent years, voted to reject almost all Commerce Clause challenges to federal statutes, regardless of the judges' party or background views of federalism. ${ }^{28}$ This

\footnotetext{
${ }^{23}$ These points connect well to Peter Strauss' famous justification for the rule of deference to the reasonable interpretive views of administrative agencies. See Chevron U.S.A., Inc. v. Natural Resources Defense Council, 467 U.S. 837 (1984). Strauss argues that Chevron is best justified as a means of ensuring that national statutes are given a nationally uniform interpretation. Absent Chevron, the regional circuit courts will predictably give statutes different de novo interpretations, and the Supreme Court's capacity to resolve circuit conflicts may prove an inadequate solution. The Chevron Court thus acted to centralize interpretive authority in national agencies by requiring the regional courts to defer to the agencies' readings. See Peter L. Strauss, 150 Cases Per Year: Some Implications of the Supreme Court's Limited Resources for Judicial Review of Agency Action, 87 Colum. L. Rev. 1093 (1987).

${ }^{24}$ The empirical political-science literature suggests that a surprising amount of lower-court conflict goes unresolved. See S. Sidney Ulmer, The Supreme Court's Certiorari Decisions: Conflict as a Predictive Variable, 78 Am. Polit. Sci. Rev. 901 (1984): 901-11 (finding that, between 1947 and 1976, the Court denied certiorari in more than half the cases involving conflict with Supreme Court precedent or intercircuit conflict). The importance of the conflicts that go unresolved is of course a separate question. For overviews of the literature on that question, including the 1970s debate over proposals to create a national appellate tribunal, below the Supreme Court, to resolve intercircuit conflicts, see Michael F. Sturley, Observations on the Supreme Court's Certiorari Jurisdiction in Intercircuit Conflict Cases, 67 Tex. L. Rev. 1251 (1989); Stephen L. Wasby, Intercircuit Conflicts in the Courts of Appeals, 63 Mont. L. Rev. 119 (2002).

${ }^{25}$ See J.W. Peltason, Fifty Eight Lonely Men: Southern Federal Judges and School Desegregation (1971).

${ }^{26}$ Antonin Scalia, Vermont Yankee: The APA, the D.C. Circuit and the Supreme Court, 1978 Sup Ct. Rev. 345 (1978).

${ }^{27}$ Brannon P. Denning \& Glenn H. Reynolds, Rulings and Resistance: The New Commerce Clause Jurisprudence Encounters the Lower Courts, 55 Ark. L. Rev. 1253 (2003); Adrian Vermeule, Does Commerce Clause Review Have Perverse Effects?, 46 Vill. L. Rev. 1325 (2001).

${ }^{28}$ See Brannon P. Denning \& Glenn H. Reynolds, Rulings and Resistance: The New Commerce Clause Jurisprudence Encounters the Lower Courts, 55 Ark. L. Rev. 1253 (2003); Cass R. Sunstein et al., Ideological Voting on Federal Courts of Appeals: A Preliminary Investigation, (May 9, 2003)(unpublished
} 
reluctance to press the Commerce Clause revolution is a nontrivial obstacle to the Court's new federalist majority, which typically waits for some lower court to invalidate a federal statute on federalism grounds before confirming the invalidation. ${ }^{29}$ Although no legal rule prevents the Court from invalidating a federal statute after the lower courts have uniformly sustained it, to do so would be a departure from the Court's ordinary certiorari practices. Overall, it is reasonable to speculate that the new federalist majority would prefer lower courts to do some of the work of the Commerce Clause revolution themselves, actively implementing the Court's decisions rather than bucking against the new Commerce Clause logic.

Instability within the Supreme Court. Even if, per impossible, lower courts were perfect agents for the Supreme Court, the principal is itself multiple, composed of nine Justices. Irreducible disagreement, aggregation problems, shifting alliances and shifting membership over time combine to create systematic instability in interpretive doctrine, preventing the sustained judicial coordination that is necessary if interpretive doctrines are to be justified on dynamic grounds. The high court that is supposed to coordinate the hierarchical system is itself riven by disagreement, plagued by mistaken or disingenuous opinion writing, destabilized by aggregation problems, and buffeted by political change. Occasionally, to be sure, the jurisdiction's high court will come into the hands of a persistent and stable majority, one that can for a few years pursue a sustained course of coordinated action. Perhaps the Warren Court was like that, for a few years anyway, and below we will see that the Rehnquist Court has attempted to coordinate on new procedural rules for congressional lawmaking in constitutionally sensitive areas, such as federalism. But the Rehnquist Court is also a statistical anomaly in many respects, especially in the length of its Justices' service. It is far more typical in American law that campaigns of coordinated action by high courts break down with surprising rapidity; we will see a few examples in the next section.

The claim is not, of course, that judicial coordination on interpretive doctrine is somehow impossible. We might imagine circumstances in which a united majority of the Supreme Court sticks to an interpretive doctrine or strategy, brings lower courts into line through aggressive oversight, and produces hoped-for reactions from other lawmaking institutions. My suggestion is simply that judicial coordination on interpretive doctrines and strategies is costly and unstable, and thus tends to be both relatively rare and noticeably fragile. In this practical and institutional sense, rather than some logical sense, judicial coordination on ambitious interpretive doctrines and strategies is generally infeasible.

B. Examples from Statutory Interpretation

Some concrete examples will serve to illustrate the consequences, or costs, of the division fallacy. I begin, in this section, with examples from statutory interpretation; Section C offers parallel examples from constitutional interpretation.

manuscript, on file with author); Sarah C. Rispin, Of Courts and Consequences: The Lower Courts, the New Commerce Clause, and the Endangered Species Act (unpublished manuscript, on file with author).

${ }^{29}$ This was the pattern in United States v. Lopez 514 U.S. 549 (1995) and United States v. Morrison 529 U.S. 598 (2000). 
1. Information-forcing default rules.

A common normative claim in interpretive theory is that judges should adopt information-forcing or democracy-forcing default rules: interpretive doctrines designed to encourage legislators to reveal their preferences explicitly or to focus their deliberations on particular questions. These rules have become a favorite of a wide range of theorists who, starting from various premises, hope that interpretive rules and canons of construction may be used to elicit useful information or behavior from legislatures. The conceptual mistake common to these proposals and arguments is that they all treat courts as a unitary actor. These proposals cannot survive the recognition that judges are numerous, that judicial institutions are partially decentralized, and that (in consequence of these facts) judicial attempts to coordinate on the relevant interpretive approaches are plagued by instability.

Textualism. Textualists often argue for the primacy of statutory text over legislative history on democracy-forcing grounds. A central argument for textualism is that it improves legislative performance: judicial refusal to remake enacted text forces Congress to legislate more responsibly ex ante. ${ }^{30}$ The argument can also be put in the language of information-eliciting default rules: adherence to text will prod legislative coalitions into revealing their preferences explicitly. ${ }^{31}$

The canon of avoidance. An important interpretive canon, or maxim, is that idea that statutes should be construed to avoid serious constitutional questions, where it is fairly possible to do so. Although the canon's supporters propose a range of justifications, an important one is the idea that avoidance will elicit desirable deliberative behavior from legislators. Absent the canon, legislators might cross constitutional limits inadvertently, or by indirection. The canon thus encourages legislators to focus their deliberations on the statute's limits and the extent to which the statute presses constitutional law in new directions; at the very least legislators will be forced to speak clearly, perhaps in statutory text, if they wish to raise a serious constitutional question.

Clear statement rules. The canon of avoidance is a general precept that statutes should be interpreted to avoid serious constitutional questions. Courts have developed a potpourri of similar canons that either (1) apply the general precept by construing statutes to avoid particular types of constitutional questions or that (2) construe statutes to promote "underenforced" constitutional norms - constitutional principles that courts are reluctant to enforce through full-fledged judicial review on the constitutional merits. Examples in the second category, sometimes called "clear statement rules," include the ideas that statutes should be narrowly construed to avoid raising the question whether Congress has unconstitutionally delegated its legislative power to an administrative

\footnotetext{
${ }^{30}$ See, e.g., United States v. Taylor, 487 U.S. 326, 346 (1988) (Scalia, J., concurring) (“[W]e have an obligation to conduct our exegesis in a fashion which fosters th[e] democratic process [specified in Article I's bicameralism amd presentment requirements"); Garrett, supra note ---, at --- (“[M]ethods like textualism and rules of clear statement are best understood as efforts to improve the quality of the decisionmaking in the politically accountable branches"); W. David Slawson, Legislative History and the Need to Bring Statutory Interpretation Under the Rule of Law, 44 Stan. L. Rev. 383, 407-10 (1992) (arguing that judicial recourse to legislative history results in irresponsible and incoherent congressional lawmaking).

${ }^{31}$ See supra TAN --- (describing analogies between contracts scholarship on information-eliciting default rules and the canons of construction).
} 
agency; ${ }^{32}$ that statutes should be construed to avoid the question whether the statute unconstitutionally intrudes on traditional or essential state functions, ${ }^{33}$ and that statutes should be presumed prospective. ${ }^{34}$ In all of these cases, the standard justifications for clear statement rules prominently feature the democracy-forcing idea that "constitutionally sensitive questions . . . will not be permitted to arise unless the constitutionally designated lawmaker has deliberately and expressly chosen to raise them." 35

The rule of lenity. The rule of lenity is a venerable interpretive canon holding that penal statutes should, where fairly possible, be construed in favor of defendants. Here the democracy-forcing idea is that legislators should be encouraged to deliberate about criminal punishment and speak clearly when they decide to adopt it.

A standard criticism of such information-eliciting or deliberation-forcing rules is that they rest upon mistaken empirical premises about legislative behavior and capacities. ${ }^{36}$ Perhaps Congress is in a strong sense institutionally incapable of fulfilling the procedural demands that these doctrines make; more weakly, perhaps the costs of congressional adaptation to those procedural demands are greater than any resulting benefits. The division problem suggests a different critique, one focused on judicial rather than legislative institutions: Information-forcing or deliberation-forcing arguments assume that judges can and will coordinate on the relevant canons, doctrines and precepts. Such arguments thus ignore the inevitable heterogeneity and fluctuation of interpretive doctrine across courts and over time.

If all (relevant) courts consistently eschewed legislative history, or consistently adhered to clear statement rules, or to the rule of lenity, Congress might encode policy choices in text, squarely face important constitutional questions, and speak clearly when imposing criminal punishments. But the federal judiciary persistently disagrees about the merits of these doctrines and about their applicability in particular settings, both within courts, such as the Supreme Court, and across courts, such as the courts of appeals. These persistent disagreements produce shifting coalitions and mutable doctrines; there is no consistent, unified set of incentives to which Congress might respond, and no steady judicial policy of democracy-forcing or information-eliciting interpretation.

With respect to each of these interpretive tools-legislative history, clear statement rules, and the rule of lenity-both variation and fluctuation are the norm, not the exception. As for legislative history, the Supreme Court has alternately emphasized and downplayed it in an oscillating pattern. Its use rose from 1937 until about 1950, fell again until the late $1950 \mathrm{~s}$, then fluctuated uncertainly until a dramatic upward spike in the mid1970s. Another slow decline began in the mid-1980s, but usage rose again in the mid 1990s before falling yet again towards the end of the decade. ${ }^{37}$ At any given time, the Court's opinions vary in their willingness to resort to legislative history, even where that

\footnotetext{
${ }^{32}$ Food and Drug Administration v. Brown \& Williamson Tobacco Corp., 529 U.S. 120 (2000); AT\&T Corp. v. Iowa Utilities Bd., 525 U.S. 366 (1999).

${ }^{33}$ Gregory v. Ashcroft, 501 U.S. 452 (1991).

${ }^{34}$ Landgraf v. USI Film Prods., 511 U.S. 244 (1994).

${ }^{35}$ Cass R. Sunstein, Nondelegation Canons, 67 U. Chi. L. Rev. 315, 331 (2000).

${ }^{36}$ Phillip Frickey \& Steven Smith, Judicial Review, the Congressional Process, and the Federalism Cases: An Interdisciplinary Critique, 111 Yale L J 1707 (2002).

${ }^{37}$ Adrian Vermeule, The Cycles of Statutory Interpretation, supra note ---, at 185-87.
} 
history is available. This persistent instability means that the textualist resurgence led by Justice Scalia is most unlikely to produce a sustained disciplining or democracy-forcing effect on statutory drafting. "Because Justice Scalia's critique never has commanded a majority on the Supreme Court, its principles cannot be attributed to the Court as a whole, let alone to lower courts." 38

The same broad pattern of fluctuating, inconsistent usage holds true of the clear statement rules and the rule of lenity. As to the former, the Rehnquist Court's favored substantive canons differ markedly from the Burger Court's, which in turn differ from the Warren Court's;, ${ }^{39}$ all in all, "these norms constitute a kind of ad hoc, judicial policymaking that Congress, ex ante, would find difficult to predict." ${ }^{, 40}$ As to the rule of lenity, "judicial enforcement of lenity is notoriously sporadic and unpredictable. As often as not, the 'instinctive distaste' for extinguishing individual liberty without clear legislative warrant gives way to other tastes that can be satisfied only by broad readings of federal criminal statutes." 41

The upshot is that at any given time some courts, panels or opinions use the relevant interpretive tools, and some do not. Even where a given canon is nominally invoked, different judges or courts assign it markedly different weights. The rule of lenity, for example, is sometimes treated as a strong presumption, sometimes as a weak tiebreaker; while clear statement rules vary both in their strength and in the sources that may be used to rebut them - text alone, text or legislative history, and so on. ${ }^{42}$ This variety and fluctuation make democracy-forcing or information-eliciting arguments premised on the universal and sustained coordination of judicial behavior seem at best optimistic, at worst futile.

Indeed, in a regime marked by intractable variation across judges, courts and decisions, and by fluctuation over time, the standard assumption -- that any particular judge ought to vote as she would if all other judges were to vote the same way -- may be worse than futile; it may be affirmatively counterproductive or perversely harmful. ${ }^{43}$ If other courts, or other judges at different times, do not use democracy-forcing approaches or information-eliciting canons, then local or episodic use by particular judges may produce bad case-specific consequences without the beneficial systemic and dynamic effects said to justify the approach. Consider an isolated textualist decision that eschews legislative history on the theory that universal judicial textualism would have beneficial, democracy-forcing effects. If legislators' expectations are shaped by the bulk of decisions that do not adopt such a theory, then the isolated textualist decision will affirmatively

\footnotetext{
${ }^{38}$ Victoria F. Nourse \& Jane S. Schacter, The Politics of Legislative Drafting: A Congressional Case Study, 77 NYU L Rev 575 (2002).

${ }^{39}$ William N. Eskridge, Jr. \& Phillip P. Frickey, Quasi-Constitutional Law: Clear Statement Rules as Constitutional Lawmaking, 45 Vand. L. Rev. 593 (1992).

${ }^{40}$ Jane S. Schacter, The Confounding Common Law Originalism in Recent Supreme Court Statutory Interpretation: Implications for the Legislative History Debate and Beyond, 51 Stan. L. Rev. 1 (1998).

${ }^{41}$ Dan M. Kahan, Lenity and Federal Common Law Crimes, 1994 Sup. Ct. Rev. 345.

${ }^{42}$ William N. Eskridge, Jr., Phillip P. Frickey and Elizabeth Garrett, Legislation and Statutory Interpretation (2000).

${ }^{43}$ The general point is that in many situations, uncoordinated idealistic or altruistic action by particular individuals can produce results that are morally or pragmatically inferior to universal inaction, even though the morally or pragmatically best results would be produced if everyone, collectively, acted altruistically. See J. Howard Sobel, “'Everyone,' Consequences, and Generalization Arguments,” 10 Inquiry 373 (1967).
} 
misread legislators' instructions. The same point holds in reverse: an isolated decision consulting legislative history, on the ground that universal judicial intentionalism would produce beneficial consequences, is at best futile and at worst perverse, if the enacting majority deliberately encoded its preferred policy in text while leaving legislative history to manipulation by dissenters.

In these examples, the cost of the division fallacy is that sporadic or isolated use of a rule or canon justified on systemwide grounds produces decisions that are mistaken on any plausible account of statutory interpretation. Suppose that a given court, or panel, or judge justifies a dispositive invocation of the rule of lenity on the ground that it forces Congress to speak clearly to criminal punishments; suppose also that other courts, panels or judges aren't using the rule, or are suing only in a weaker version, or inconsistently. Then an isolated instance of its use by one court will have no democracy-forcing effect; it merely gives the particular criminal defendant in the case at hand a windfall victory even though all other interpretive sources (text, legislative history, and so on), minus the rule of lenity, suggest that the statute covers the defendant's conduct. That might be a good or bad thing, for independent reasons, but it cannot be justified as a democracy-forcing or information-eliciting approach.

2. Positive models of interpretive dynamics.

So far the examples have involved normative arguments for particular interpretive canons. A second class of examples involves positive models of the dynamics of legislation. Consider the ingenious models recently advanced by sophisticated intentionalists to rebut textualist claims about legislative history. In these models, intentionalist statutory interpretation produces a self-fulfilling equilibrium: courts consider legislative history as accurate, and rational legislators anticipating the practice monitor legislative history to ensure that it does indeed accurately reflect the deal struck by the enacting coalition. ${ }^{44}$ Textualism might also produce a self-fulfilling equilibrium, albeit with the players coordinated on text rather than history. But if disagreement, mistakes and noncompliance, voting cycles or legal and political change cause different judges or courts to do different things with legislative history at different times, then no equilibrium model that implicitly depicts the judiciary as a unitary actor is very impressive; a more refined approach is necessary. The same point holds as against the whole class of rational models that portray constitutional and statutory interpretation as the product of a unitary judiciary, or simply an abstract "court.",45

\footnotetext{
${ }^{44}$ McNollgast [Matthew D. McCubbins, Roger G. Noll, Barry R. Weingast], Positive Canons: The Role of Legislative Bargains in Statutory Interpretation, 80 Geo. L.J. 705 (1992).

${ }^{45}$ William N. Eskridge Jr., John Ferejohn \& Neeta Gandhi, Strategic Statutory Interpretation, Paper presented at Modeling the Constitution Conference (May 17, 2003) available at http://lawweb.usc.edu/cslp/pages/conferences/modeling_const_02/eskridge.pdf; William N. Eskridge Jr. \& John Ferejohn, The Article I, Section 7 Game, 80 Geo. L. J. 523 (1992); Einer Elhauge, PreferenceEstimating Statutory Default Rules, 102 Colum. L. Rev. 2027 (2002); Einer Elhauge, Preference-Eliciting Statutory Default Rules, 102 Colum. L. Rev. 2162 (2002). Matthew C. Stephenson, 32 JLS 59 (2003), makes the interesting suggestion that even when the judiciary is "discussed as if it were a unitary actor," this need not assume a centralized system of judicial review, id. at 65 . But then it is not clear how conflict among lower courts is to be resolved; Stephenson's model assumes, by brute force, that judicial rulings can be aggregated into a single "ruling" that represents "the total outcome of all judicial decisions that affect the legality of any aspect of government policy." Id. at 66.
} 
To be sure, ever-more-sophisticated rational choice models might be constructed to account for the mutability and inconsistency of judicial interpretation. Perhaps, in a more complicated model, legislators might assess the probability that judges will use various interpretive strategies, resulting in an expected-value calculus that will tell legislators to decide how much to invest in creating text, legislative history, or other interpretive sources. But this sort of model would put even more strain than usual on our credulity about legislators' rationality, information and computational abilities. If exceedingly strong assumptions are needed to describe an equilibrium, perhaps the game is not worth the candle. Even if the necessary assumptions are not outlandish, recognizing the division problems that result from the collective character of judicial institutions require important modifications of the standard positive models of interpretive dynamics.

\section{The distributive effects of interpretive method}

With respect to both the normative and positive examples given above, the most general point is that the choice of interpretive method has controversial substantive and distributive consequences. Interpretation is not a pure exercise in coordination across judges and courts; interpretive method also determines, or helps to determine, whose preferences the legal system satisfies, and to what degree. To be sure, many interpretive doctrines and canons do have a coordination component. The best outcome, from the systemic point of view, might be that all judges should adhere either to a rule of lenity or to a rule of severity, rather than mucking about inconsistently. But choosing canons, or choosing between textualism or legislative history, isn't much like choosing whether to drive on the left side of the road or the right. ${ }^{46}$ It is a mixed game of coordination and distribution, ${ }^{47}$ in which judges desire to coordinate, but some judges would prefer that all coordinate on one particular rule, while other judges would prefer that all coordinate on a different rule.

\footnotetext{
${ }^{46}$ William N. Eskridge, Jr. \& John Ferejohn, "Politics, Interpretation, and the Rule of Law" (Nomos 1993) 283, use this analogy to describe canonical regimes. This analogy portrays interpretation, quite implausibly, as a pure coordination problem. Although Eskridge and Ferejohn elsewhere recognize that interpretive regimes have distributive effects, see id. at 284, they do not explain how to reconcile that point with their earlier analogy, nor do they consider the possibility that the distributive effects of alternative regimes may produce systematic conflict and interpretive instability within the judiciary. A similar ambiguity inheres in Fred Schauer's claim that "plain meaning" interpretation can serve a "coordinating function" among judges who are "attempting to reach some methodological consensus in the face of substantive disagreements among them.” Frederick Schauer, Statutory Construction and the Coordinating Function of Plain Meaning, 1990 Supreme Court Review 231. It is not clear whether this is intended to describe a pure coordination game, or a mixed game of coordination and distribution in which different judges receive different payoffs from coordinating on one result or another.

${ }^{47}$ Usually modeled as "The Battle of the Sexes," in which Male wants to attend a quilting bee, Female wants to watch roller hockey, but each would prefer to attend the other's event rather than spend the evening alone. See, e.g., Eric Rasmusen, Games and Information: An Introduction to Game Theory 31 (1989). Given the distributive effects of interpretive choices, David Strauss suggests, persuasively, that the Battle provides a better lens for understanding constitutional interpretation than do pure coordination games. See David A. Strauss, Common Law, Common Ground, and Jefferson's Principle, 112 Yale L.J. 1717,1734 (2003). Although focal points can produce stable equilibria in the Battle, as well as in pure coordination games, see id; James D. Morrow, Game Theory for Political Scientists 94-97 (1994), it is also possible that no stable cooperative regime will emerge, because players "hold out for a distribution of benefits of a regime more favorable to their immediate interests." James D. Morrow, "Modeling the Forms of International Cooperation: Distribution versus Information," 48 International Organization 387, 413 (1994). I take this latter possibility to represent the chronic condition of judicial interpretation.
} 
Thus sophisticated intentionalists argue that a self-fulfilling equilibrium centered on legislative history is superior to an equilibrium centered on text, on the ground that the former better suits the organizational constraints under which legislatures act. ${ }^{48}$ Likewise, a leading criticism of the Rehnquist Court's frequent recourse to clear statement rules emphasizes that the Court's preferred rules, rather than being neutral coordinating regimes that merely allow legislators to signal their choices, inevitably have controversial normative and distributive implications. ${ }^{49}$ The Court's presumptive canons favor federalism, property rights and other values, but the opposite presumptions would equally favor the opposite values, so normative argument and substantive conflict over the content of the interpretive regime is unavoidable. Finally, the rule of lenity will produce fewer convictions than would a rule that criminal statutes should be broadly construed ("the rule of severity"), and different judges will have (different) extrinsic reasons for preferring one outcome to the other. In all of these areas, the distributive consequences of alternative canons and interpretive tools are precisely what create the persistent disagreement, inevitable noncompliance, and political shifts that in turn prevent judges and courts from attaining the coordination benefits of uniform interpretive rules. ${ }^{50}$

\section{Examples from Constitutional Interpretation}

Parallel examples are to be found in the theory and practice of constitutional interpretation.

\section{Due process of lawmaking}

It is tempting to think that constitutional theorizing is intrinsically less susceptible to the division fallacy. Interpretive theorizing that assumes coordinated judicial action, the argument might run, is only relevant when the theorist hopes that judicial interpretation will influence the behavior of legislators in statutory drafting and of agencies in administrative rulemaking. Constitutional interpretation, on this view, is not forwardlooking in the same way. After all, most of the Constitution's text is fixed, and amendments are rare events, so that adopting interpretive doctrines with a view to their deliberation-forcing effects on constitutional drafters would be pointless.

But this is wrong. Many constitutional rules and doctrines are (said to be) justified on the ground that they will have valuable forward-looking effects on the behavior of current legislators. Under the general rubric of "due process of lawmaking," theorists have proposed a variety of precepts, approaches and doctrines that structure the legislative process with a view to improving legislative deliberation and action. These doctrines universally assume that the requisite judicial action can easily be coordinated; they commit the division fallacy, in other words, by assuming that if it would be good for all

\footnotetext{
${ }^{48}$ Eskridge \& Ferejohn, Nomos, supra note _ at 277.

${ }^{49}$ Eskridge \& Frickey, Quasi-Constitutional Law, supra note _.

${ }^{50}$ In light of this point, it is unsurprising that legislatures rarely enact statutory rules of statutory interpretation, and that when they do those rules tend to restrict themselves to narrow grammatical canons without distributive import, or to large-scale abstractions. See, e.g., 1 U.S.C. $§ 1$ (a short collection of definitions and uncontroversial interpretive rules); Statutory Construction Act of 1972, 1 Pa. Cons. Stat. $\S 1501$ (2002). The distributive consequences of substantive interpretive rules may often prevent legislatures from attaining sufficient agreement on any particular interpretive code. For the constitutional questions surrounding such legislation, see Nicholas Quinn Rosenkranz, Federal Rules of Statutory Interpretation, 115 Harv. L. Rev. 2085 (2002).
} 
courts to adopt a particular strain of due process of lawmaking, it would be good for a particular court or judge to do so.

Requirements of congressional factfinding. The Rehnquist Court's revival of constitutional federalism has been criticized and defended, in part, on due process of lawmaking grounds. In the Commerce Clause area, United States v. Lopez suggested, in part, that the validity of national legislation might turn, not on the Court's independent assessment of the statute's connection to commerce, but instead on the quality and quantity of the record evidence that Congress had provided to demonstrate a commercial connection. The later decision in Morrison v. United States, however, seemed to reject the due-process-of-lawmaking strand in Lopez. In cases arising under Section 5 of the 14th Amendment, the procedural strain has been quite marked. In Kimel v. Florida Board of Regents and Board of Trustees v. Garrett, the Court invalidated federal statutes subjecting states to suit under the ADEA and ADA, holding that, in both cases, the congressional findings accompanying the statute failed sufficiently to document the factual and legal predicates (a pattern of unconstitutional state behavior) necessary for congressional action. The Court usually leaves the point of these requirements unstated, but the only plausible account is that the Court is using constitutional invalidation as a sanction to encourage congressional factfinding, and perhaps even deliberation of a certain kind and quality.

Standard criticisms of the Rehnquist Court's resort to due process of lawmaking techniques focus on legislative capacities and prerogatives. One idea is that Congress is structurally incapable of supplying the sort of judicialized factfinding and deliberation the Court is demanding; ${ }^{51}$ another idea is that these cases have bad expressive dimensions, suggesting a lack of interbranch comity and judicial respect for congressional autonomy. Given the fallacy of division, however, we may add another point: the Rehnquist Court's due-process-of-lawmaking enterprise, requiring as it does a steady course of coordinated judicial action, is extremely vulnerable to fluctuations in judicial behavior over time and to disagreements within the decentralized judiciary.

Those sources of instability have already begun to operate in the Commerce Clause cases. At the Supreme Court level, consider the contrast between Lopez's interest in legislative procedure and Morrison's exclusive focus on substance. Suppose that some Justice, at the time of Lopez, joined the majority solely on the basis that a requirement of congressional factfinding, if consistently adopted by the whole Court, would eventually have beneficial effects on the quality and depth of congressional deliberation. The hidden premise of the argument is that judicial coordination of this sort is feasible, not only in the case at hand but for the time necessary to alter congressional behavior. If, and to the extent that, the assumption fails because the requisite judicial coordination is infeasible, then a due-process-of-lawmaking approach resting on that assumption must fail as well.

To be sure, the new federalist majority did hang together in Morrison, even if it discarded the democracy-forcing rationale for Lopez. A separate problem is that even a temporarily unified Court majority may be unable to force its agenda on the lower courts, who can hamper the Court's plan by simple failure to render active cooperation. As we have seen, that is just what has occurred in the Commerce Clause cases: the lower courts have, overwhelmingly, declined to extend the Court's precedents to new federal statutes,

${ }^{51}$ Frickey \& Smith, Interdisciplinary Critique, supra note _ at 1737. 
even where a fair reading of Morrison would suggest that invalidation is the obvious outcome. ${ }^{52}$ So even if the due process of lawmaking rationale still animated the Court's Commerce Clause precedents, its effect might well have been diluted by lower-court recalcitrance.

Overbreadth and legislative deliberation. A similar example is the free speech overbreadth doctrine. Roughly speaking - the conceptual and doctrinal disputes here are exceedingly refined ${ }^{53}$ - overbreadth doctrine permits a litigant whose own conduct is constitutionally proscribable to challenge a statute on the ground that it has a nontrivial range of applications that violate the free speech rights of parties not before the court. So a statute that sweeps too broadly, combining constitutional applications with unconstitutional ones, will be invalidated in whole, not just in part, if it impinges on free speech (although not if it impinges on most other constitutional rights). Although overbreadth has been supplied with a variety of justifications, one idea is that "[o]verbreadth doctrine . . provid[es] an incentive to legislatures to draft laws that may affect First Amendment activity with as much precision as practicable., 54

That rationale holds only to the extent that the judiciary can coordinate, across judges and over time, on the relevant conception of overbreadth doctrine. But there is little reason to think that this sort of sustained judicial coordination is feasible. Consider Massachusetts v. Oakes, in which Justice O'Connor's plurality opinion said that an overbreadth claim becomes moot if the statute is amended, after the defendant's conviction, to eliminate the portion of the statute that the defendant challenges as overbroad. $^{55}$ This seemingly technical position is actually critical, for it would demolish the ex ante, democracy-forcing justification for overbreadth. As Justice Scalia noted in a partial concurrence that, on this point, attracted five (!) votes, under the plurality's rule the legislature might promulgate an overbroad law and then simply narrow the statute before the final appeal, thereby saving any convictions obtained under the initially overbroad statute. $^{56}$

Justice Scalia's incentive-based view is not the law, however, at least according to the judge-made rules governing the stare decisis effect of fractured decisions; three of the five votes supporting his view appeared in a dissenting opinion, and votes do not aggregate across judgments in this way. ${ }^{57}$ Since Oakes, various lower federal courts, and

\footnotetext{
${ }^{52}$ See supra notes ---.

${ }^{53}$ See Richard H. Fallon, Jr., As-Applied and Facial Challenges and Third-Party Standing, 113 Harv. L. Rev. 1321 (2000); see also Matthew D. Adler, Rights, Rules, and the Structure of Constitutional Adjudication: A Response to Professor Fallon, 113 Harv. L. Rev. 1371 (2000).

${ }^{54}$ Alan K. Chen, Statutory Speech Bubbles, First Amendment Overbreadth, and Improper Legislative Purpose, 38 Harv. Civ. Rts.- Civ. Lib. L. Rev. 31 (2003); Broadrick v. Oklahoma, 413 U.S. 601, 611-12 (1973) (overbreath ensures that speech restrictions "represent a considered legislative judgment that a particular mode of expression has to give way to other compelling needs of society.").

${ }_{55}$ Massachusetts v. Oakes, 491 U.S. 576 (1989).

56 "It seems to me strange judicial theory that a conviction initially invalid can be resuscitated by postconviction alteration of the statute under which it was obtained." Massachusetts v. Oakes, 492 U.S. 576, 586 (1989) (Scalia, J., concurring).

${ }^{57}$ See Martin v. Commonwealth, 96 S.W.3d 38, 53 (Ky. 2003) (noting that "the five votes fragmented between concurring and dissenting opinions in Oakes cannot be characterized as a 'holding' for purposes of stare decisis") (citing Gregg v. Georgia, 428 U.S. 153, 169 n.15 (1976)).
} 
state courts, have reached opposing results on similar facts. ${ }^{58}$ A later decision from the Supreme Court, Osborne v. Ohio, ${ }^{59}$ further complicated the issue by holding that an overbreadth challenge could be mooted by a post-enactment judicial narrowing, rather than legislative narrowing, of the challenged statute. Given this inconsistency across courts, and arguable variation over time, it would be foolish for any judge to adopt Justice Scalia's forward-looking account of overbreadth, in the hopes that coordinated judicial action will discipline legislative behavior in speech-sensitive areas.

2. The theory of precedent and retaliatory judicial activism

What theory of precedent should judges adopt in deciding constitutional cases? Accounts of precedent typically assume that all judges, including future judges, will coordinate on the same approach. The theoretical problems facing any particular judge who adopts any given approach will, however, change dramatically when other judges adopt different approaches.

Consider a story like the following. At Time 1, a particular account of precedent prevails in the legal system. This account might hold, for example, that a precedent decided at Time 1 may be overruled by a court sitting at Time 2 only if there is some special justification for overruling it. At Time 1 the jurisdiction's highest court issues a precedent decision. Under the prevailing account of precedent, it is not permissible for the Time 2 court to overrule the earlier decision just because its members think that decision erroneous. When Time 2 is reached, however, the judges then sitting happen to hold a different account of precedent. Under this account, judges may overrule any earlier decision that is mistaken, in their current view. So the Time 2 court overrules the earlier decision and substitutes a precedent decision that is the opposite of the earlier one.

Now imagine a judge sitting at Time 3. This judge subscribes to the account of precedent that prevailed at Time 1 - that is, precedents may not be overruled unless there is special justification for so doing; it is not enough that the earlier precedent be erroneous. On this view, to which precedent does the Time 3 judge owe allegiance- the decision issued at Time 1, or the overruling decision issued at Time 2? From the standpoint of the Time 3 judge, the overruling decision was erroneous; it invoked a mistaken theory of precedent, and under the correct theory the Time 1 decision would still be the law. The very theory of precedent that brands the Time 2 overruling as mistaken, however, also bars the Time 3 judge from voting to overrule the Time 2 decision just because it was erroneous. The theory held by the Time 3 judge can be interpreted in procedural or substantive terms, and these interpretations now have sharply different implications.

This story is not fanciful; similar accounts are ubiquitous in constitutional law. Consider two narratives commonly encountered in originalist legal discourse:

- Before 1937, the Supreme Court issued restrictive decisions about the scope of national legislative power, the delegation of legislative power to agencies, and other topics. After 1937 these decisions were overruled, in some cases on the

\footnotetext{
${ }^{58}$ The Martin court found Justice Scalia's reasoning "persuasive," and so followed it anyway, see 96 S.W.3d at 53. The Sixth Circuit, however, disagrees. See Kentucky Right to Life v. Terry, 108 F.3d 637, 644-45 (1997).

${ }^{59}$ Osborne v. Ohio, 495 U.S. 103 (1990).
} 
simple ground that then-sitting Justices thought them mistaken. Should the current Court adhere to the overruling decisions, even though they were methodologically flawed, or reinstate the overruled decisions, even though to do so would require the current Court to adopt the same aggressive approach to overruling precedent that the post-1937 decisions adopted?

- The Warren and Burger Courts casually overruled a great many criminalprocedure precedents, expanding criminal defendants' constitutional rights in many settings. Moreover, the Court made some of its rulings prospective, in part to weaken the constraints of stare decisis (because prospectivity reduces the cost of overruling precedents). Should the current Court respect the Warren and Burger Court precedents, or should those decisions be treated in the same cavalier fashion as the older decisions they overruled?

The point here is not to assert that either of these accounts is historically accurate; it is merely to use them to illustrate the quandary that the Time 3 judge faces. What should the Time 3 judge do? There is no answer internal to the theory of precedent that the Time 3 judge holds, because the theory is at odds with itself: its procedural instruction is to uphold the Time 2 decision, while its substantive counsel is that the Time 1 decision should be reinstated as the law that would obtain has the correct account of precedent been followed. The Time 3 judge must choose between these two possibilities on other grounds entirely.

Some will counsel the Time 3 judge to do as he would have others do, adhering to the procedural counsel of his theory. Others will counsel the Time 3 judge to engage in a form of retaliatory activism: the judge should vote to overrule the Time 2 decision, even in violation of his theory's procedural counsel, in order to restore the law to the state that would obtain if the theory had been followed by all prior judges. ${ }^{60}$ Proponents of the latter course will claim that failure to engage in retaliatory activism will, over time, produce a sort of ratchet effect: "conservative" courts-here defined as courts that afford great weight to stare decisis - will respect the decisions of "liberal" courts-here defined as courts that afford little weight to stare decisis. But liberal courts will not respect the decisions of conservative courts. Over time, legal change will systematically tend to come from liberal courts. If those courts also tend to be liberal in the political sense, the ratchet will also have a political valence over time.

These dilemmas arise because theories of precedent vary among judges and over time. Theories of precedent typically recommend that any particular judge adopt the theorist's approach because that approach would be best if adopted by all judges. But many other judges will adopt different approaches; when they do, accounts of precedential decisionmaking that implicitly require or assume generalization will go badly awry. Theories of precedent vary across judges and over times for the same reason that different judges prefer different canons of statutory interpretation and different approaches to constitutional interpretation: theories of precedent inevitably have controversial normative and distributive implications. To praise "conservative" judging as "restrained" because it respects past precedent is to build in a presumption in favor of existing distributions of legal rights, economic and property entitlements, and social

\footnotetext{
${ }^{60}$ I take this to be Stephen Smith's basic argument. Stephen F. Smith, Activism as Restraint: Lessons from Criminal Procedure, 80 Va. L. Rev. 1057 (2002).
} 
conditions. To condemn conservative judging, so defined, is to build in systemic pressure for legal change. Over time, different judges with different preferences about the pace of legal change, and about the substantive valence of change in different periods, will adopt varying approaches to stare decisis. Any account of stare decisis that implicitly requires that account to generalize across courts and over time is, on this view, so unlikely as to be no account at all.

$* * * * *$

We may sum up the division problem as follows. In the examples above, the division fallacy seduces theorists of statutory interpretation into errors of inadmissible generalization. The implicit premise of such theorizing -- any approach that would be desirable if adopted by all judges should therefore be adopted by any particular judgetreats judicial institutions as unitary rather than riven by chronic disagreement, noncompliance with agreed-upon rules, and political conflict. Disagreement and conflict might be called the circumstances of judicial politics; ${ }^{61}$ they arise from changing economic and social conditions and from the distributive effects of competing approaches to interpretation. It is a conceptual mistake for interpretive theorists to proceed as though the judiciary is a unitary, rather than collective, actor. And the conceptual mistake has doctrinal consequences. Recognizing the division fallacy undermines a range of positions, doctrines and arguments, including the dynamic justification for textualism, the idea that canonical regimes can serve as democracy-forcing or information-eliciting default rules, and the Rehnquist Court's flirtation with due process of lawmaking.

If all this is right, what's a judge to do? The answer is simply that interpretive rules, precepts and doctrines cannot be justified on dynamic grounds. Dynamic justifications assume ideal conditions for judicial coordination, conditions that cannot be attained by the decidedly non-ideal structure of judicial institutions. To reiterate, that negative conclusion leaves other types of arguments untouched; other grounds may be available for the conclusions whose dynamic justifications have been erased. Thus textualists who must abandon the ex ante, democracy-forcing justification for textualism may fall back upon other, non-dynamic justifications for the primacy of constitutional or statutory text; and intentionalists who must abandon the picture of legislative history as a self-fulfilling interpretive regime may turn to other arguments for legislative history. Eliminating dynamic arguments nonetheless represents progress, for it rescues arguments about interpretive theory from an intellectual dead end into which they have recently strayed.

\section{The FALLACY OF COMPOSITION}

The conceptual error that underlies the composition fallacy is a mistake about generalization, a mistake that is a mirror-image of the division fallacy. In the division case, the theorist errs by assuming that if some interpretive approach is desirable when adopted by the whole court or judiciary, it must also be desirable when adopted by an individual judge. In the composition case, the theorist errs by assuming that if some interpretive approach is desirable when adopted by an individual judge, it must also be desirable when adopted by the whole court or judiciary. We have seen that the former

\footnotetext{
${ }^{61}$ With a debt to Waldron's idea of the "circumstances of politics," itself indebted to Rawls" "circumstances of justice," which in turn is adapted from Hume. See Jeremy Waldron, Law and Disagreement 102 (Oxford University Press 1999); John Rawls, A Theory of Justice 109 (Rev. ed., Belknap Press 1999)(1971).
} 
inference fails. The latter also fails if and to the extent that methodological diversity is a desirable property of courts or of the whole judiciary. In economic terms, individual judges adopt approaches at the margin, but not every judge can be at the margin. An interpretive approach might be best when adopted by the additional or marginal judge, but not best when adopted by all judges.

A. Is Judicial Coordination Desirable?

Why might interpretive approaches be desirable at the margin but not globally? The basic reason, which we may express in several different ways, is the possibility that a diversity of interpretive approaches has good consequences for judicial institutions and for the lawmaking system as a whole. To fall into the division fallacy is to overlook that sustained judicial coordination on a uniform interpretive approach may be infeasible; to fall into the composition fallacy is to overlook that judicial coordination on a particular approach may be affirmatively harmful.

Here I mean to put aside (at least) three other kinds of diversity that a judiciary or court might display, in addition to diversity of interpretive method: racial and gender diversity, political diversity, and class diversity. As a positive matter, all these types of diversity may overlap, to some uncertain degree, if the relevant traits are correlated. It would not be shocking to discover, for example, that minority judges, or female judges, tend to be disproportionately appointed by Democratic presidents and also tend to be disproportionately inclined to wield nonformalist interpretive methods. But it is unclear to what extent these correlations exist in fact. It would also be quite plausible to discover, for example, that interpretive approaches are largely uncorrelated with either of the other two modes of diversity.

Normatively, we may ask whether any of these types of diversity is good in itself or has good consequences for the institutions of interpretation. Although it is possible to imagine a claim that judicial diversity of race, gender, politics or class is valuable in itself, or in expressive terms, it is hard to imagine a parallel claim for methodological diversity; interpretive approaches have no intrinsic significance or normative appeal, apart from their consequences for the legal system. I will thus restrict myself to the question whether methodological diversity has good consequences. My treatment here is largely derivative of important recent work on judicial diversity. ${ }^{62}$ The contribution of this Part, if any, is to situate the topic of judicial diversity in the larger intellectual framework of generalization mistakes.

Whatever the state of the judiciary's racial and gender composition, or its political mix, methodological diversity might have distinct, and distinctly valuable, consequences. Although having a court composed of, for example, all textualists might be better (or worse) than having a court composed of all purposivists, it might be best of all to have a mixture of approaches. ${ }^{63}$ The following reasons, among others, might support such a view:

\footnotetext{
${ }^{62}$ See Cass R. Sunstein, Conformity and Dissent, University of Chicago Public Law and Legal Theory Working Paper No. 34, Chapter 7, December 2002; Cass R. Sunstein \& David A. Strauss, The Senate, The Constitution, and the Confirmation Process, 101 Yale L.J. 1491 (1992).

${ }^{63}$ I will confine the discussion to the benefits of methodological diversity within the highest court in the judicial hierarchy. It has been shown, however, that ideological diversity at lower levels of the hierarchy can conserve on the costs of judicial administration, by allowing high-court judges to use the known
} 


\section{Preventing polarization ${ }^{64}$}

Likeminded judges share empirical assumptions and normative commitments that may be exaggerated by the presence of other likeminded judges. One possibility is group polarization: the possibility that, as to issues that range along a single dimension (say, whether to give more or less weight to the rule of lenity), deliberating groups of likeminded judges will polarize in the direction of the predeliberation mean, and will thus go to extremes. Where the predeliberation mean is bimodal, so that opposing views are each well-represented, this effect is suppressed. So methodological diversity may prevent courts or panels from skewing their decisions in implausible or unexpected ways.

\section{Moderation of competing approaches}

The previous point suggests that diversity of interpretive approaches, methods and perspectives will tend to moderate judicial approaches and outcomes. Suppose, for example, that interpretive formalism is not an on-off switch, but a continuum. We might well imagine that a group of textualist judges might always interpret statutes and constitutional provisions in a highly literalistic fashion, a group of purposivist judges might always interpret statutes and constitutional provisions in an extremely plastic, policy-sensitive fashion, and a group with diverse approaches would often follow the apparent meaning of legal texts but might occasionally tailor text to reasonable conceptions of original intentions or purposes.

Is this moderation good? Theorists strongly committed to one approach or the other might say that moderation is neither here nor there. If a moderate court gets the right outcome (as judged by the theorists' preferred approach), then moderation is good; otherwise it is not. Polarizing in the right direction is good; in the wrong direction, bad. But this point, unimpeachable from within any particular interpretive theory, is not helpful from the standpoint of the optimal design of judicial institutions. From the systemic perspective, the problem is how judicial institutions should be arranged given that many different camps of interpretive theorists each claims that its preferred approach is uniquely correct, and given that this disagreement over the correct interpretive theory seems intractable, at least for the foreseeable future. Under these circumstances, moderation has much to recommend it. The system designer who is uncertain which of the possible approaches is best might be wise to hedge the risks of wholesale adoption of one approach and wholesale rejection of its competitors. A methodologically diverse judiciary is, plausibly, the best way to minimize the risk that any particular approach will have bad consequences for the interpretive system.

A more pragmatic objection is that moderation might trade off against the variance of outcomes. A bench composed solely of strict textualists, or of unsophisticated purposivists, might produce more predictable (even if more extreme) decisions than a bench featuring a mixture of interpretive approaches, just as a panel of extreme left-wing (or right-wing) judges might produce more predictable decisions than a mixed panel. Perhaps this is so, but perhaps it is not. For one thing, a bench of (say) all textualists might produce a set of decisions with equal variance, but now centered around a

ideology of lower-court judges as a screening device to reduce the number of decisions that must be reviewed on appeal. See Matt Spitzer \& Eric Talley, Judicial Auditing, 29 J. Legal Stud. 649, 651 (2000).

64 The discussion here draws heavily on Sunstein, Conformity and Dissent, supra note ---. 
different, more extreme mean. For another, there are critical questions here about the relative determinacy of the various approaches. Is purposivism inherently unpredictable, just because constitutional and statutory purposes can be described at any level of generality? Is textualism extremely manipulable? And so forth. This is another area in which the necessary empirical work is lacking, so that the only feasible procedure is to make an informed guess that methodological diversity is, on net, valuable for the interpretive system.

\section{Legitimation for multiple audiences}

The audience for judicial decisions extends far beyond the litigants, or even other lawmaking institutions; it encompasses informed elites in the legal profession, the legal academy and universities generally, and the public. Different sectors of this audience have different convictions, often firmly held, about the proper approach to constitutional and statutory interpretation. The rulings of a methodologically diverse court might appeal to a broader segment of this audience than the rulings of a methodologically homogenous one. An originalist court might please originalist while dismaying nonoriginalists, while a diverse court might produce rulings that create a greater overall level of satisfaction, and enjoy wider acceptance.

As with the parallel arguments about the feasibility of judicial coordination, the foregoing ideas provide empirical possibilities, institutional variables, to be taken into account as theorists consider the optimal design of the institutions of interpretation. The point is not to argue, on the merits, that interpretive diversity is desirable. It is instead to say that the possibility cannot be assumed away. The relevant questions must be asked and answered before the generalization from individual approaches to court-wide approaches can be made.

\section{B. Examples}

Two examples, one constitutional and one statutory, will suffice to illustrate the potential benefits of a methodologically diverse judiciary.

\section{Formalism and functionalism in separation of powers law}

The constitutional law bearing on separation of powers is famously riven by opposing methodological camps: so-called formalists and functionalists. There are many different ways of construing these opposing ideas and of understanding what, if anything, formalists and functionalists disagree about; a rough description suffices for our purposes here. Formalists argue for attention to text and original understanding, for rule-bound adjudication, and for clear lines of demarcation between the branches of the federal government (except insofar as the branches have explicit authority to participate in each other's activities; the President's veto power is an example). For formalists, the critical threshold question is whether the challenged authority counts as an exercise of federal "legislative," "executive," or "judicial" power. Once that categorization is made, the Constitution attaches authorities and obligations to the relevant power, and the challenged action is then scrutinized for conformity to the constitutional allocation. Functionalists argue for flexible adaptation of the separation of powers to the exigencies of modern government, for standard-based or balancing approaches to separation-of-powers adjudication, and for participation by each branch in the decision-making processes of other branches. The separation of powers does not prohibit interaction of branches or the 
commingling of their functions. It prohibits one branch from appropriating or intruding upon the "core functions" 65 of other branches.

Would a Supreme Court composed of both of separation-of-powers formalists and functionalists do better, or worse, than a bench composed solely of committed adherents of one or the other approach? Plausibly the answer is better. That answer will seem incoherent to partisans of either view. After all, each side will say (agreeing on this although nothing else), whether the Court can be said to do well in any particular case depends on whether it has adopted the correct approach to separation of powers law; and the correct approach just is the approach that we favor (formalism or functionalism; here irreducible disagreement resurfaces).

It is reasonable to suppose, however, that formalism and functionalism lie on a continuum, so that a Court, or its median member, may at any given time adopt a moreor-less formalist or functionalist approach. It is also reasonable to think that, on this continuum, it is best to avoid extremes. A Court staffed solely by Justice Rehnquists and Whites would systematically undervalue the virtues of a rule-like approach to separation of powers adjudication: stability, predictability, and fidelity to text and original constitutional design. A bench of this sort might approve ill-considered improvisations, hasty institutional arrangements that tamper with the Constitution's deep structure. In hindsight Morrison v. Olson ${ }^{66}$ looks just like a case of this sort; the independent counsel law was, on this view, a harmful solution to a nonexistent problem. Perhaps a Court with more separation-of-powers formalists would not have rejected, by a 7-1 vote, Justice Scalia's prescient dissent. On the other hand, the extremes of formalism also look unattractive; a bench composed solely of separation-of-powers formalists might choke off valuable structural reform, producing excessive rigidity in the lawmaking system. Consider the line-item veto decision, Clinton v. New York, ${ }^{67}$ which uses strained formalist arguments to invalidate a bipartisan innovation that has been widely adopted in the states, and that is precious hard to distinguish from ordinary delegations of impoundment authority to the President. Indeed Clinton v. New York is formalist in another, pejorative sense as well: the opinion conceals the majority's real concern, a nondelegation idea about transfers of excessively open-ended authority to the President, behind a dogmatic reading of the relevant constitutional texts.

These examples suggest that a well-functioning approach to the separation of powers would minimize the sum of two types of errors: harmful decisions by political actors to tamper with constitutional structure for short-term advantage or poorly-deliberated ends, on the one hand, and judicial rejection of valuable institutional innovations, on the other. Formalist judges are especially alert to the first type of mistake, functionalist judges to the second. Plausibly, a bench composed of both formalists and functionalists might detect enough of both errors to minimize their sum, relative to a uniform bench of either stripe. From the systemic standpoint, although not from the standpoint of methodological partisans, a court composed of judges with diverse views about separation-of-powers law would produce better structural constitutional law than a court with uniform views in either direction.

\footnotetext{
${ }^{65}$ United States v. Nixon, 418 U.S. 683 (1974).

${ }^{66}$ Morrison v. Olson, 487 U.S. 654 (1988).

${ }^{67}$ Clinton v. City of New York, 524 U.S. 417 (1998).
} 


\section{Interpreting statutes to avoid absurd results}

Parallel arguments apply to the question, widely debated in the theory of statutory interpretation, whether and when judges ought to interpret statutes to avoid absurd results. Interpretive functionalists, intentionalists and purposivists are particularly alert to cases in which statutory text is overinclusive or (more rarely) underinclusive with respect to plausible conceptions of legislators' intentions or purposes. These interpreters propose that courts should have wide discretion to mold statutes to fit their underlying objectives and to avoid the bizarre or unjust consequences of literalism. Statutory formalists or textualists, on the other hand, are alert to detect cases in which the judicial interpretation to avoid absurd results creates rather than avoids mistakes. On the formalist view, purposivist judges are sometimes ill-informed about the precise contours of the compromise struck in the legislative process, mistakenly discern absurdities that an expert understanding of the relevant policies would show to be perfectly sensible, import contestable or unattractive value premises into the determination of statutory purpose, or underestimate the systemic values of certainty and clarity of legal obligations that (formalists claim) flow from resolute adherence to statutory text.

Here too, a reasonable view is that statutory formalism is not a quality that is either present or absent, but a continuum; judges may be more or less formalist or functionalist. It is also reasonable to think that neither extreme on the continuum is attractive or even tenable for the judicial system as a whole. Both camps can, and incessantly do, point to preferred examples that illustrate the flaws in the competing approach. Formalists stumble over examples such as the Arkansas statute that inadvertently repealed the State's entire code of laws; ${ }^{68}$ what is the alternative to invoking absurdity in a case like that? Functionalists stumble over examples like the Holy Trinity case, in which the Supreme Court invoked the absurd-results canon to exempt an English minister from a statute that prohibited contracting with an alien to perform labor or service of any kind in the United States. The Court said that the statute should not be read to apply to "brain toilers" or, because this is a "Christian" nation, to ministers. The decision not only had elitist and sectarian undertones; it was also (I have argued) mistaken about the statute's purposes, in part because it misunderstood the legislative deliberation that produced the relevant statutory text. ${ }^{69}$ The general point is that a bench composed of both formalists and functionalists might do the best job of detecting and preventing both sorts of mistakes, thus minimizing their sum; a bench staffed solely by one camp or the other might do worse overall.

It might be objected that the real point of all this has nothing to do with diversity. On this view, the point of the examples would be, not that courts should be composed of methodologically diverse judges, but just that courts should adopt a moderate stance that avoids mistakes at either extreme. A court composed of a single judge - the limiting case of nondiversity - might, on this view, get all the cases right if the judge is sufficiently skilled at avoiding the mistakes that arise from either excessive formalism or functionalism. In principle, as a matter of ideal theory, this objection is correct. But the problem is that no actual judges, in the non-ideal world of the judicial system, are capable of infallibly striking the optimum. Methodological diversity across a number of judges

\footnotetext{
${ }^{68}$ Cernauskas v. Fletcher, 201 S.W.2d 999, 1000 (1947).

${ }^{69}$ Vermeule, Holy Trinity Church, supra note _, at 1845.
} 
harnesses the partial and fallible commitments, expertise and prejudices of different types of judges, alert to different types of mistakes to which interpretation is prone, and enlists them to produce the best overall results for the system as a whole.

$* * * * *$

If methodological diversity is desirable, what follows? For the individual judge, plausibly the answer is nothing at all. We would not want to say that a judge whose prior beliefs or commitments are (for example) textualist should try to adopt an intentionalist approach in order to diversify a largely textualist court, or vice-versa for an intentionalist on a largely textualist court. That counsel would be psychologically unrealistic. People do not put on or take off interpretive approaches like a suit of clothes; such approaches are deeply-held jurisprudential commitments. But to ask what follows for the individual judge is, on the analysis here, not the right question. The benefits of methodological diversity are systemic rather than individualized, so they should be promoted at the systemic level. To the extent that methodological diversity is desirable, presidents have a systemic obligation to appoint nominees - true believers in whichever approach is currently under-represented - who will diversify the courts to which they are appointed. And senators have a systemic obligation to cast confirmation votes with the benefits of methodological diversity in mind, rather than simply attempting to stock courts with a uniform cast of likeminded interpreters.

\section{LEGAL THEORY AND THE UNITARY JUDICIARY}

I have suggested that legal theory stumbles into generalization mistakes when, and because, it assumes that the judiciary may be understood as a unitary actor rather than a collective bureaucracy. But why does that mistake occur? Here I shall canvass, in an admittedly speculative way, some conceptual errors and academic tendencies that promote and perpetuate the assumption of a unitary judiciary.

A. Modeling Imperatives

In its most benign version, the assumption of a unitary judiciary is not a factual or normative claim about actual judicial institutions. It is rather an explicitly methodological premise, one used by theorists developing positive rational-actor models of the interpretive process - the dynamic interaction between Congress, agencies and courts - in order to make the necessary models mathematically tractable. After all, a fully realistic model of the institutional interactions that shape constitutional and statutory interpretation would be as complicated as the lawmaking system itself. It would thus be unhelpful for academic purposes; simplified models isolate the comparative statics of the interpretive system. I said above that positive models that treat the judiciary as a unitary actor might not, in fact, tell us very much that is useful about those comparative statics; more complex models would incorporate the collective character of judicial institutions, and would model legislators' responses to the risk of, or uncertainty about, shifting interpretive methods that arise from disagreement and aggregation problems in collective courts. But that point is just an internal criticism of the current work in positive political theory. It is consistent with the view that positive theorists can, and surely will, construct models of ever-greater utility and refinement.

In this limited methodological sense the assumption of a unitary judiciary is unobjectionable. What is objectionable, however, is the confusion between the map and 
the territory: the use of simplified formal models, premised on a unitary judiciary, to support normative recommendations to actual institutional actors who occupy the real world of a collective judicial bureaucracy, not the stylized world of positive political theory. Models that describe interaction between a legislature-often taken to be a collective and internally complex body - and a unitary "court" or single judge cannot support any normative recommendation whatsoever to judges on actual multimember courts situated in multicourt judicial hierarchies. Any attempt to leverage a positive model that depicts the interaction between a legislature (or legislators) and a unitary, internally boneless "court" into a normative recommendation to an actual court, or worse yet the individual judges of that court, is just a semantic equivocation-a play on two crucially different senses of the word.

B. The Approximation Assumption

I also said above that some accounts of interpretation do not require coordinated judicial action; they are thus untouched by generalization problems. Suppose, however, that an account of interpretation does require coordinated judicial action. Suppose also that a judge who subscribes to that account, or a theorist urging judges to subscribe to that account, argues along these lines: "To be sure, it is clear that not all judges will act on the account I favor, because of disagreement, mistakes, aggregation problems, and so forth. So the ideal of systemwide coordination I hold is unattainable. But it is nonetheless a worthy ideal, and we usually think it praiseworthy, perhaps even morally obligatory, to pursue our ideals as far as possible, even if we will never fully attain them. Perhaps the radiant power of the example I set, in strictly adhering to the approach that would be best for all to adopt, will eventually persuade all others to adopt it." Is the argument sound?

Not at all. It rests on the approximation assumption: the fallacious view that the best course of action is the one that approximates an unobtainable ideal as closely as possible. ${ }^{70}$ To the contrary, if an ideal state of affairs cannot be fully realized, partial implementation of the ideal is often worse, as judged by the very criteria that support the ideal in the first place, than abandoning it entirely. ${ }^{71}$ We have already seen examples of this in various interpretive settings. Consider the possibility that, even if a textualist approach would be best for the interpretive system as a whole (if all judges were textualists), a pattern of frequent recourse to legislative history combined with isolated or sporadic textualist decisions might be worse, even or especially to committed textualists, than universal intentionalism or purposivism.

The empirical or psychological connection between the approximation assumption and the assumption of a unitary judiciary is that the former belief tends to generate and sustain the latter one. The implicit reasoning might run as follows: (1) Any particular judge should strictly adhere to the approach that would be best if adopted by all, even if other judges will not adopt the same approach (the approximation assumption). Therefore (2) the interaction among judges' differing views is normatively irrelevant, and (3) interpretive theorizing may proceed as though there is only a single judge, even if we all know that the judiciary is a collective body (the unitariness assumption). There is, of course, no logical compulsion to follow this chain of reasoning; I am making a

\footnotetext{
${ }^{70}$ Avishai Margalit, Ideals and Second Bests, in Philosophy for Education, Seymour Fox ed., 77 (DafChen, 1983).

${ }^{71}$ See Sobel, supra note, at 379.
} 
psychological claim about the typical, implicit thought process of judges and academics interested in interpretive theory.

C. The Judge as Artist ${ }^{72}$

There is a romantic strand of legal theory that celebrates the artistry of the sole judge. This theoretical style portrays common-law judging, especially, as a creative activity, at worst as an ineffable craft, in which the judge "molds" or "shapes" precedents to meet social needs; Cardozo's opinion in Buick v. McPherson is perhaps the exemplar. Constitutional and statutory interpretation, on these premises, is merely an extension of common-law adjudication. The relevant texts don't matter much, at least once they are sufficiently encrusted with precedents that a later judge may in good conscience proceed through common-law elaboration.

In this romantic picture of judging, little attention is paid to the collective structures of adjudication. Artists do not create by committee. The shifting views, intellectual compromises, and humdrum arrangements that are the very stuff of collective adjudication-incoherent opinions written to attract a majority vote; the implicit logrolling of judicial coalitions; the cert pool-have no place in the artistic conception, which is of the law, as crystallized in academically impressive opinions, working itself pure. Here there is no room for bothersome others, dimwitted colleagues whose disagreement, or noncompliance, or mutating preferences, slow or halt the march towards the unitary constitutional truth as delivered by the unitary judge. It is embarrassing enough to think that the creative activity of molding law to social ends might be shot through with the explicit compromises and tacit accommodations needed to produce collective agreement on decisions. To think that the structural conditions of collective judging might make it infeasible for courts to shape law into deeply coherent patterns is to abandon the picture of judicial artistry altogether.

\section{CONCLUSION: IDEAL AND NONIDEAL INTERPRETIVE THEORY}

We might roughly distinguish two styles of interpretive theory, ideal and nonideal. Ideal interpretive theory is concerned with the ultimate normative aims of legal interpretation: the ideal interpreter should attempt to read constitutional and statutory provisions in ways that make the best sense of law's implicit principles, or that accord with the best current theories in linguistics and semantics, that comport with the deep structural logic of the Constitution's separation of powers, or that promote social justice, suitably understood. Nonideal interpretive theory is a different enterprise. It asks how nonideal interpreters of law should proceed, in light of widespread disagreement about competing ideal theories, and given the institutional constraints and political conditions that actually obtain in particular legal systems (especially our own).

Recognizing the collective structure of constitutional and statutory interpretation by judges, and the resulting inevitability of disagreement, incoherence, and instability in the theory and practice of judicial interpretation, push strongly in the direction of nonideal interpretive theory. The point is not, on this view, that ideal interpretive theory is worthless or conceptually mistaken. But ideal interpretive theory can never, even in principle, support normative recommendations addressed to actual interpreters in an

72 Robert Weisberg, The Calabresian Judicial Artist: Statutes and the New Legal Process, 35 Stan. L. Rev. 213 (1983). 
actual legal system (judges or others). Ideal theory must always be translated through supplemental nonideal premises about institutional capacities and performance, the effects of disagreement across interpreters, and the changing political forces that buffet the lawmaking system.

The point that nonideal questions are inescapable is, I have suggested, especially damaging to a particular class of arguments in ideal interpretive theory. Arguments of this sort assume both that each particular judge should do what would be best if done by all judges, and also that all judges should do what it would be best for any particular judge to do. Such arguments assume, in other words, that judicial coordination on a particular interpretive approach is both feasible and desirable. The first assumption commits the fallacy of division, the second commits the fallacy of composition.

These are conceptual mistakes, but they have important doctrinal consequences. The two fallacies of interpretive theory are pervasive, I suggest, in dynamic arguments that would justify textualism by its disciplining effect on legislatures; that praise canons of construction, or interpretive default rules, by pointing to their democracy-forcing or information-eliciting effects; and that justify constitutional rules by reference to their beneficial effects on the lawmaking process. Dynamic arguments of this sort are not merely wrong, in a substantive sense; they are conceptually invalid. That claim is a strictly negative or critical one, to be sure. But we must clear the ground for nonideal interpretive theory; for nonideal theory is the only kind of interpretive theory that nonideal judges can use. 
Readers with comments may address them to:

Professor Adrian Vermeule University of Chicago Law School 1111 East 60th Street

Chicago, IL 60637

a-vermeule@uchicago.edu 


\section{University of Chicago Law School}

\section{Public Law and Legal Theory Working Paper Series}

1. Cass R. Sunstein and Edna Ullmann-Margalit, Second-Order Decisions (November 1999; Ethics, v. 110, no. 1).

2. Joseph Isenbergh, Impeachment and Presidential Immunity from Judicial Process (November 1999; forthcoming Yale Law and Policy Review v.18 \#1).

3. Cass R. Sunstein, Is the Clean Air Act Unconstitutional? (August 1999; Michigan Law Review \#3).

4. Elizabeth Garrett, The Law and Economics of "Informed Voter" Ballot Notations (November 1999, University of Virginia Law Review, v. 85).

5. David A. Strauss, Do Constitutional Amendments Matter? (November 1999)

6. Cass R. Sunstein, Standing for Animals (November 1999)

7. Cass R. Sunstein, Culture and Government Money: A Guide for the Perplexed (April 2000).

8. Emily Buss, Without Peers? The Blind Spot in the Debate over How to Allocate Educational Control between Parent and State (April 2000).

9. David A. Strauss, Common Law, Common Ground, and Jefferson's Principle (June 2000).

10. Curtis A. Bradley and Jack L. Goldsmith, Treaties, Human Rights, and Conditional Consent (May 2000; Pennsylvania Law Review v. 149).

11. Mary Ann Case, Lessons for the Future of Affirmative Action from the Past of the Religion Clauses? (May 2001, Supreme Court Review, 2000)

12. Cass R. Sunstein, Social and Economic Rights? Lessons from South Africa (May, 2000).

13. Jill Elaine Hasday, Parenthood Divided: A Legal History of the Bifurcated Law of Parental Relations

14. Elizabeth Garrett, Institutional Lessons from the 2000 Presidential Election (May 2001).

15. Richard A. Epstein, The Allocation of the Commons: Parking and Stopping on the Commons (August 2001).

16. Jack Goldsmith, The Internet and the Legitimacy of Remote Cross-Border Searches (October 2001).

17. Adrian Vermeule, Does Commerce Clause Review Have Perverse Effects? (October 2001).

18. Cass R. Sunstein, Of Artificial Intelligence and Legal Reasoning (November 2001).

19. Elizabeth Garrett, The Future of Campaign Finance Reform Laws in the Courts and in Congress, The William J. Brennan Lecture in Constitutional Law (December 2001).

20. Julie Roin, Taxation without Coordination (March 2002).

21. Geoffrey R. Stone, Above the Law: Research Methods, Ethics, and the Law of Privilege (March 2002; forthcoming J. Sociological Methodology 2002). 
22. Cass R. Sunstein, Is There a Constitutional Right to Clone? (March 2002).

23. Emily Buss, Parental Rights (May 2002, forthcoming Virginia Law Review).

24. David A. Strauss, Must Like Cases Be Treated Alike? (May 2002).

25. David A. Strauss, The Common Law Genius of the Warren Court (May 2002).

26. Jack Goldsmith and Ryan Goodman, U.S. Civil Litigation and International Terrorism (June 2002).

27. Jack Goldsmith and Cass R. Sunstein, Military Tribunals and Legal Culture: What a Difference Sixty Years Makes (June 2002).

28. Cass R. Sunstein and Adrian Vermeule, Interpretation and Institutions (July 2002).

29. Elizabeth Garrett, Is the Party Over? The Court and the Political Process (August 2002).

30. Cass R. Sunstein, The Rights of Animals: A Very Short Primer (August 2002).

31. Joseph Isenbergh, Activists Vote Twice (November 2002).

32. Julie Roin, Truth in Government: Beyond the Tax Expenditure Budget (November 2002).

33. Cass R. Sunstein, Hazardous Heuristics (November 2002).

34. Cass R. Sunstein, Conformity and Dissent (November 2002).

35. Jill Elaine Hasday, The Principle and Practice of Women's "Full Citizenship": A Case Study of Sex-Segregated Public Education (December 2002).

36. Cass R. Sunstein, Why Does the American Constitution Lack Social and Economic Guarantees? (January 2003).

37. Adrian Vermeule, Mead in the Trenches (January 2003).

38. Cass R. Sunstein, Beyond the Precautionary Principle (January 2003).

39. Adrian Vermeule, The Constitutional Law of Congressional Procedure (February 2003).

40. Eric A. Posner and Adrian Vermeule, Transitional Justice as Ordinary Justice (March 2003).

41. Emily Buss, Children's Associational Rights? Why Less Is More (March 2003)

42. Emily Buss, The Speech Enhancing Effect of Internet Regulation (March 2003)

43. Cass R. Sunstein and Richard H. Thaler, Libertarian Paternalism Is Not an Oxymoron (May 2003)

44. Elizabeth Garrett, Legislating Chevron (April 2003)

45. Eric A. Posner, Transfer Regulations and Cost-Effectiveness Analysis (April 2003)

46. Mary Ann Case, Developing a Taste for Not Being Discriminated Against (May 2003)

47. Saul Levmore and Kyle Logue, Insuring against Terrorism - and Crime (June 2003)

48. Eric Posner and Adrian Vermeule, Accommodating Emergencies (September 2003)

49. Adrian Vermeule, The Juddiciary Is a They, Not an It: Two Fallacies of Interpretive Theory (September 2003) 